\title{
Tracking the best reference genes for RT-qPCR data normalization in filamentous fungi
}

\author{
Agustina Llanos ${ }^{1,2,3,4}$, Jean Marie François ${ }^{1,2,3}$ and Jean-Luc Parrou ${ }^{1,2,3^{*}}$
}

\begin{abstract}
Background: A critical step in the RT-qPCR workflow for studying gene expression is data normalization, one of the strategies being the use of reference genes. This study aimed to identify and validate a selection of reference genes for relative quantification in Talaromyces versatilis, a relevant industrial filamentous fungus. Beyond $T$. versatilis, this study also aimed to propose reference genes that are applicable more widely for RT-qPCR data normalization in filamentous fungi.

Results: A selection of stable, potential reference genes was carried out in silico from RNA-seq based transcriptomic data obtained from $T$. versatilis. A dozen functionally unrelated candidate genes were analysed by RT-qPCR assays over more than 30 relevant culture conditions. By using geNorm, we showed that most of these candidate genes had stable transcript levels in most of the conditions, from growth environments to conidial germination. The overall robustness of these genes was explored further by showing that any combination of 3 of them led to minimal normalization bias. To extend the relevance of the study beyond T. versatilis, we challenged their stability together with sixteen other classically used genes such as $\beta$-tubulin or actin, in a representative sample of about 100 RNA-seq datasets. These datasets were obtained from 18 phylogenetically distant filamentous fungi exposed to prevalent experimental conditions. Although this wide analysis demonstrated that each of the chosen genes exhibited sporadic up- or down-regulation, their hierarchical clustering allowed the identification of a promising group of 6 genes, which presented weak expression changes and no tendency to up- or down-regulation over the whole set of conditions. This group included $u b c B$, sac7, fis1 and sarA genes, as well as TFC1 and UBC6 that were previously validated for their use in $\mathrm{S}$. cerevisiae.

Conclusions: We propose a set of 6 genes that can be used as reference genes in RT-qPCR data normalization in any field of fungal biology. However, we recommend that the uniform transcription of these genes is tested by systematic experimental validation and to use the geometric averaging of at least 3 of the best ones. This will minimize the bias in normalization and will support trustworthy biological conclusions.
\end{abstract}

Keywords: Filamentous fungi, Talaromyces, RNA-seq, RT-qPCR, Reference genes, Normalization, Gene expression

\section{Background}

Filamentous fungi are involved in several natural and industrial processes. They have long been used for the production of additives used in food and beverages [1]. Some fungi produce enzymes that degrade lignocellulosic material with applications in food, feed, textile, pulp and paper industries [2,3]. The genera Penicillium

\footnotetext{
* Correspondence: jean-luc.parrou@insa-toulouse.fr

'Université de Toulouse; INSA, UPS, INP; LISBP, 135 Avenue de Rangueil,

F-31077 Toulouse, France

${ }^{2}$ INRA, UMR792 Ingénierie des Systèmes Biologiques et des Procédés,

F-31400 Toulouse, France

Full list of author information is available at the end of the article
}

and Aspergillus are the most biotechnologically important fungi, due to their ability to produce secondary metabolites, organic acids or enzymes, but recent genome sequences of hundreds of fungal species indicate that the potential of fungi has been substantially underestimated $[4,5]$. Talaromyces is another industrially relevant genus closely related to Penicillium [6], among which Talaromyces versatilis is exploited for the production of a commercial cocktail called "Rovabio Excel" that is used as feed additive for enhancing digestibility of cereal based diets. However, fungi are not restricted to biotechnologically relevant organisms. Recent estimates suggest that more than 5 million fungal species exist in this 
monophyletic kingdom, the huge majority being in the Ascomycota and Basidiomycota phyla [7]. Fungi have considerable impact in agriculture, as fungi are capable of intimate symbiotic associations with plants as in the case of Rhizophagus irregularis [8] while some species are economically serious plant pathogens [9], e.g. Leptosphaeria maculans [10], Blumeria graminis [11], Rhizoctonia solani [9,12], Magnaporthe grisea [13]. Finally, they not only draw interest as pathogens of invertebrate animals, but they are also harmful for human health, as for example with the production of mycotoxins and allergens [14], with several species, including Aspergillus fumigatus, causing invasive disease [15]. For all these reasons, and aided by extraordinary advances in genome sequencing facilities [16,17], there has been a tremendous effort to pursue the sequencing of filamentous fungi. The availability of genomic sequences from several fungi has favoured the rapid development of high throughput transcriptomic studies and functional genomics analysis.

Better knowledge of gene function usually begins by investigating expression of the genes of interest (GOIs) under a broad set of culture conditions. Several techniques have been developed to measure expression levels, among which the coupling between reverse transcription and quantitative (real-time) PCR (RT-qPCR) appears to be the most appropriate to study limited numbers of genes in large sets of conditions $[18,19]$. Significant technical advances made this mRNA quantification method very accessible, highly specific and sensitive, but numerous critical issues remain that limit the ability to draw meaningful conclusions [20]. The Minimum Information for Publication of Quantitative RealTime PCR Experiments (MIQE) guidelines help in the design of experiments, to keep track of the experimental data and to improve analysis [21,22]. Importantly, and no matter what the technique for measuring gene expression is, data normalization is a critical step. Performance and pitfalls of the different normalization strategies has already been compared in a number of dedicated review articles [19,23]. Few articles promote the use of external controls [24,25], a normalization strategy stimulated by the ERCC or EQUAL-quant programs $[26,27]$, and especially relevant for the assessment of technical robustness in clinical and biological diagnostic laboratories. But normalization of gene expression levels by reference genes (internal controls) is most certainly the gold standard, even if it is now clearly established that the use of a single gene is not acceptable, as there is not a single gene that has a stable transcript level over all kinds of culture conditions or among different cell types [28-31]. The main challenge concerning these internal controls is the circular problem in evaluating expression stability of a candidate normalization gene [32], i.e. how can the expression stability of a candidate be evaluated if no reliable measure is available to normalize the candidate? To overcome this circular problem, Vandesompele et al. [33] first developed more than ten years ago a method called geNorm, which allows the evaluation and ranking of candidate reference genes in terms of expression stability (or suitability as normalizing gene). In a subsequent step, the algorithm is able to indicate how many reference genes are optimally required to remove most of the technical variation. Other algorithms were then developed (e.g. Normfinder [32] or BestKeeper [34]) and were presented in a comprehensive survey [28]. Good practice in data normalization for gene expression analysis therefore relies on the identification, experimental validation and use of several reference genes. In filamentous fungi, such efforts have been observed with recent publications dedicated to the validation of suitable reference genes under specific experimental contexts [35-45]. In Zhou's work [39], cypB and $c r z A$ were evaluated because of their stability in transcriptomic datasets. Similarly, Kim and Yun [46] selected 8 reference genes from transcriptomic data available with Fusarium graminearum. Such an approach was an exception, as most often, authors have evaluated more classic "housekeeping genes" encoding for example actin, glyceraldehyde-3-phosphate dehydrogenase or $\beta$-tubulin, which are still and too frequently used as single, nonvalidated reference genes.

During the course of the RNA-seq based transcriptomic analysis of the industrial strain $T$. versatilis exposed to wheat straw, it was found that most of the classical reference genes exhibited expression changes in the presence of this lignocellulosic substrate (unpublished data). This finding prompted the formulation of a list of putative reference genes and validation of their expression stability in $T$. versatilis cultivated under more than 30 different relevant conditions, following the MIQE guidelines for robust and reliable RT-qPCR expression data acquisition and treatment. Finally, 90 RNA-seq based transcriptomic datasets from 18 phylogenetically distant filamentous fungi were scrutinized, including datasets from industrially important or model species as well as plant or animal interacting fungi, to demonstrate that some of the candidate genes suitable for $T$. versatilis can be proposed as promising reference genes for data normalization in RT-qPCR analysis in other filamentous fungi.

\section{Methods}

\section{Strain and culture conditions}

The industrial strain used in this work, Talaromyces versatilis (basionyme Penicillium funiculosum, IMI378536), is an ADISSEO proprietary strain (patent no. W0 99/57325). Spores of $T$. versatilis were obtained by growing the strain 
on Potato Dextrose Agar (PDA) plates and the spores were used to inoculate liquid medium. The minimal medium (MM) contained for $1 \mathrm{~L}: 1.9 \mathrm{~g} \mathrm{KH}_{2} \mathrm{PO}_{4}, 0.65 \mathrm{~g}$ $\mathrm{KCl}, 0.65 \mathrm{~g} \mathrm{MgSO}_{4}, 12.5 \mathrm{mg} \mathrm{ZnSO}$, $12.5 \mathrm{mg} \mathrm{MnCl}_{2}$, $12.5 \mathrm{mg} \mathrm{FeSO}$, $5 \mathrm{~g} \mathrm{NH}_{4} \mathrm{Cl}$. The $\mathrm{MM}$ was supplemented with $10 \mathrm{~g} / \mathrm{L}$ glucose as the sole carbon source, unless otherwise stated. The $\mathrm{pH}$ was adjusted to 6.0 with $50 \mathrm{mM}$ $\mathrm{KH}_{2} \mathrm{PO}_{4}$. The liquid medium was inoculated with $2 \times 10^{5}$ spores $/ \mathrm{mL}$ in Erlenmeyer flasks. The cultures were carried out at $30^{\circ} \mathrm{C}$ and agitated at $150 \mathrm{rpm}$ for $48 \mathrm{~h}$.

\section{Mycelia samples}

A summary table of the culture conditions is presented as Additional file 1. To prepare mycelia samples of T. versatilis exposed to different carbon sources, the mycelia were grown for $48 \mathrm{~h}$ in MM broth culture and were filtered through Miracloth (Merck), washed with MM without carbon source and transferred to fresh media containing the desired carbon sources. The cultures were incubated from 30 minutes to 2 hours for growth on monosaccharides (arabinose $0.2 \%(\mathrm{w} / \mathrm{v})$ or xylose $0.2 \%$ ) or disaccharides (cellobiose $0.2 \%$, xylobiose $0.2 \%$ or thio-gentiobiose $0.2 \%$ ), or up to 24 hours for the cultures containing complex carbon sources (Avicel 1\%, Arbocel 1\%, beechwood xylan 1\%, ball-milled wheat straw $1 \%$ or micronized wheat bran $1 \%$ ). For exposure to stress, the T. versatilis mycelia grown for $48 \mathrm{~h}$ in $\mathrm{MM}$ medium were filtered through Miracloth, washed with MM without carbon source and transferred to MM supplemented with $0.5 \mathrm{M} \mathrm{KCl}$ for salt stress, $\mathrm{MM}$ without glucose for carbon starvation, MM without ammonium for nitrogen starvation, and $\mathrm{MM}$ with the $\mathrm{pH}$ adjusted to 2 or 8 for $\mathrm{pH}$ stress. The cultures were incubated at $30^{\circ} \mathrm{C}$ for $1 \mathrm{~h}$ before sampling. For the temperature stress, the mycelia were similarly collected and transferred to a pre-heated MM broth culture for an additional $1 \mathrm{~h}$ at $40^{\circ} \mathrm{C}$. Samples of about $50 \mathrm{mg}$ of mycelium were then collected by filtration through Miracloth and flash frozen in liquid nitrogen.

The conidia at different developmental stages were prepared after inoculating MM with $2 \times 10^{5}$ spores $/ \mathrm{mL}$. Samples were harvested by centrifugation at $3000 \mathrm{~g}$ for $2 \mathrm{~min}$, after incubation of the spores at $30^{\circ} \mathrm{C}, 150 \mathrm{rpm}$ for $2 \mathrm{~h}$ (no morphological change), $4 \mathrm{~h}$ (early swelling), $8 \mathrm{~h}$ (late swelling), $12 \mathrm{~h}$ (germ tube on one side of the conidia) and $16 \mathrm{~h}$ (hyphae already visible). $500 \mu \mathrm{L}$ of pre-heated RNA extraction buffer $(\mathrm{NaCl} 0.6 \mathrm{M}$, sodium acetate $0.2 \mathrm{M}$, EDTA $0.1 \mathrm{M}$, SDS 4\%) were added to each sample before immersing in liquid nitrogen.

\section{RNA extraction and CDNA synthesis}

Mycelia and conidia samples were mechanically disrupted using the TissueLyser II (Qiagen). Frozen mycelia samples were disrupted with a single $5 \mathrm{~mm}$ stainless steel bead (Qiagen), whereas thawed conidia preparations were mixed with approx. $150 \mu \mathrm{L}$ of $625 \mu \mathrm{m}$ glass beads (Sigma). Both were submitted to two high-speed shaking cycles of 3 minutes at $30 \mathrm{~Hz}$. Total RNA was isolated from disrupted mycelia samples using the GeneJET Plant RNA Purification Mini Kit (Thermo). An on-column DNase I treatment (Thermo - Reference \#EN0521) was added to the protocol, applying $100 \mu \mathrm{L}$ of the DNase I mix $(50 \mu \mathrm{L}$ of DNase I, $10 \mu \mathrm{L}$ of $10 \mathrm{X}$ buffer and $40 \mu \mathrm{L}$ of nucleasefree water) to the column after the first wash, for a 30 minutes incubation at room temperature and final wash with the wash buffer I. The remaining of the protocol was performed as recommended by the Supplier. For conidia and germinating conidia samples, total RNA was isolated after transfer of the liquid, beads-free phase to a tube containing $1 \mathrm{~mL}$ of TRIzol reagent (Invitrogen). $0.25 \mathrm{~mL}$ of chloroform was added to each sample and the tubes were incubated for 5 minutes at room temperature and then vortexed. The tubes were centrifuged at $16000 \mathrm{~g}$ for 15 minutes. The aqueous phase (approx. $750 \mu \mathrm{L}$ ) was transferred to a clean tube and 1 volume of isopropanol was added. The samples were mixed by inverting the tubes several times. The tubes were incubated at room temperature for 10 minutes and centrifuged at $16000 \mathrm{~g}$ for 10 minutes. The supernatant was removed and the pellet was washed with $1 \mathrm{~mL}$ of $70 \%(\mathrm{v} / \mathrm{v})$ ethanol and centrifuged once again at $16000 \mathrm{~g}$ for 10 minutes. The ethanol was discarded and the pellet was left to dry. Each pellet was resuspended in $50 \mu \mathrm{L}$ of nuclease-free water. A cleanup protocol using the RNeasy Mini Kit (Qiagen) and oncolumn DNase I treatment (Thermo) was then performed on these RNA samples.

The quantification of the RNA samples was assessed by using the ND-1000 UV-visible light spectrophotometer (NanoDrop Technologies) while the Bioanalyzer 2100 with the RNA 6000 Nano LabChip kit (Agilent) was used to certify RNA integrity. Only RNA samples with 260/280 $\mathrm{nm}$ wavelength ratio of approximately 2 and $260 / 230 \mathrm{~nm}$ wavelength ratio greater than 2 were retained for analysis. Synthesis of cDNA was performed using the PrimeScript First Strand cDNA Synthesis Kit (Takara), following the Manufacturers' protocol. One microgram of total RNA from mycelia samples and $100 \mathrm{ng}$ of total RNA from conidia and germinating conidia were used for the cDNA synthesis reaction. The cDNA was diluted 1:10 with water and stored at $-20^{\circ} \mathrm{C}$.

\section{Primer design and validation}

Primers were designed using Vector NTI advance v11 (Life Technologies) with melting temperature of $58-60^{\circ} \mathrm{C}$, length of $18-25$ bp and GC content of $50-60 \%$. All except R7 and R9 (see Table 1) possess one to several introns in their sequence, which allowed designing the primers at the exon-exon junctions to minimise the amplification of 
Table 1 List of putative reference genes and genes of interest

\begin{tabular}{|c|c|c|c|c|c|c|}
\hline Name & Annotation & GO terms & Pathway & Primer sequence & $\begin{array}{l}\text { Primers } \\
\text { efficiency }\end{array}$ & $\begin{array}{l}\text { Amplicon } \\
\text { size }\end{array}$ \\
\hline \multirow[t]{2}{*}{ R1 } & \multirow[t]{2}{*}{ DUF221 domain protein (DUF221) } & \multirow[t]{2}{*}{ Vacuolar membrane (GO:0005774) } & \multirow{2}{*}{$\begin{array}{l}\text { Transmembrane protein with } \\
\text { unknown function }\end{array}$} & Fw: CGGAACGCCCCATTGACC & \multirow[t]{2}{*}{$95.1 \%$} & \multirow[t]{2}{*}{$126 \mathrm{bp}$} \\
\hline & & & & Rv: TTGGATGCTTATGTITGGTCTCG & & \\
\hline \multirow[t]{3}{*}{ R2 } & \multirow[t]{3}{*}{ Ubiquitin carrier protein $(u b c B)$} & Ligase activity (GO:0016874) & \multirow{3}{*}{$\begin{array}{l}\text { Involved in the ubiquitin } \\
\text { mediated proteolysis }\end{array}$} & Fw: TCGTTGAGTAGACTCTGAATGCTG & \multirow[t]{3}{*}{$99.2 \%$} & \multirow[t]{3}{*}{$125 \mathrm{bp}$} \\
\hline & & $\begin{array}{l}\text { Cellular response to stress } \\
\text { (GO:0033554) }\end{array}$ & & Rv: AGCCAGATGTTCCACCCG & & \\
\hline & & Cytoplasm (GO:0005737) & & & & \\
\hline \multirow[t]{2}{*}{ R3 } & \multirow{2}{*}{$\begin{array}{l}\text { CECR1 family adenosine } \\
\text { deaminase }(A D A)\end{array}$} & \multirow{2}{*}{$\begin{array}{l}\text { Adenosine deaminase activity } \\
\text { (GO:0004000) }\end{array}$} & \multirow[t]{2}{*}{ Involved in the purin metabolism } & Fw: CTGCGCAATGCAAAGTCATGTCTCTG & \multirow[t]{2}{*}{$100.7 \%$} & \multirow[t]{2}{*}{$97 \mathrm{bp}$} \\
\hline & & & & Rv: CCCAGGTCGAAGATCCCTITATCCA & & \\
\hline \multirow[t]{3}{*}{ R4 } & \multirow{3}{*}{$\begin{array}{l}\text { Mitochondrial membrane fission } \\
\text { protein (fis } 7 \text { ) }\end{array}$} & Metal ion binding (GO:0046872) & \multirow{6}{*}{$\begin{array}{l}\text { Mitochondrial complex that } \\
\text { promotes mitochondrial fission }\end{array}$} & Fw: GTTCAACTACGCCTGGGGACTC & \multirow[t]{3}{*}{$101.1 \%$} & \multirow[t]{3}{*}{$91 \mathrm{bp}$} \\
\hline & & Mitochondrial fission (GO:0000266) & & Rv: AGCGGTGCGAAAAATCTGGG & & \\
\hline & & Membrane (GO:0016020) & & & & \\
\hline \multirow[t]{3}{*}{ R5 } & \multirow{3}{*}{$\begin{array}{l}\text { Copper-transporting ATPase } \\
\text { (Cu-ATPase) }\end{array}$} & Nucleotide binding (GO:0000166) & & FW: TGGTGCCCTGTGCCAACTCTCCCAGTC & \multirow[t]{3}{*}{$103.6 \%$} & \multirow[t]{3}{*}{$78 \mathrm{bp}$} \\
\hline & & $\begin{array}{l}\text { Cellular metal ion homeostasis } \\
\text { (GO:0006875) }\end{array}$ & & Rv: TTGCTGCGGGTGCTTTG & & \\
\hline & & Membrane (GO:0016020) & & & & \\
\hline \multirow[t]{3}{*}{ R6 } & \multirow[t]{3}{*}{ Cohesin complex subunit (psm1) } & $\begin{array}{l}\text { DNA secondary structure binding } \\
\text { (GO:0000217) }\end{array}$ & \multirow[t]{3}{*}{$\begin{array}{l}\text { Involved in chromosomes } \\
\text { segregation during mitosis }\end{array}$} & Fw: GTATTTGCGGAGATCCAGAGTGAG & \multirow[t]{3}{*}{$93.1 \%$} & \multirow[t]{3}{*}{$102 \mathrm{bp}$} \\
\hline & & $\begin{array}{l}\text { Mitotic sister chromatid segregation } \\
\text { (GO:0000070) }\end{array}$ & & Rv: TTGAAGACGGGTCTGTTCCA & & \\
\hline & & Nucleus (GO:0005634) & & & & \\
\hline \multirow[t]{3}{*}{ R7 } & Spo7-like protein (spo7) & Phosphatase activity (GO:0016791) & Involved in the spore formation & Fw: GCCGATGGTGCTGATGTTGG & $102.5 \%$ & $110 \mathrm{bp}$ \\
\hline & & Sporulation (GO:0043934) & process & Rv: AGAACGCCAACGAGCCCG & & \\
\hline & & Integral to membrane (GO:0016021) & & & & \\
\hline R8 & SAGA-like transcriptional regulatory & Transferase activity (GO:0016740) & Component of the nuclosomal & Fw: ACGACTTGTTGGCGGACG & $96.3 \%$ & $95 \mathrm{bp}$ \\
\hline & complex subunit spt3 (spts) & Chromatin modification (GO:0016568) & $\begin{array}{l}\text { nistone acetyitransferase (SAGA) } \\
\text { complex }\end{array}$ & Rv: GAGATTCAGCAGATGATGTTTGTC & & \\
\hline & & Nucleus (GO:0005634) & & & & \\
\hline R9 & DUF500 domain protein (DUF500) & $\begin{array}{l}\text { Actin filament organization } \\
\text { (GO:0007015) }\end{array}$ & Cytoskeleton organization & Fw: ACTTGGCCGGTTGTGCGTTC & $98.5 \%$ & $101 \mathrm{bp}$ \\
\hline & & Cytoplasm (GO:0005737) & & Rv: TTGGTGTTCCGGCGGCTG & & \\
\hline R10 & Rho GTPase activator (sac7) & $\begin{array}{l}\text { Rho GTPase activator activity } \\
\text { (GO:0005100) }\end{array}$ & Involved in signal transduction & FW: AGGAGGATGAAAGTAAAGGACCCC & $100.5 \%$ & $159 \mathrm{bp}$ \\
\hline & & $\begin{array}{l}\text { Small GTPase mediated signal } \\
\text { transduction (GO:0007264) }\end{array}$ & & Rv: AAACCCCACACTTGGCGAC & & \\
\hline
\end{tabular}


Table 1 List of putative reference genes and genes of interest (Continued)

\begin{tabular}{|c|c|c|c|c|c|c|}
\hline \multirow[t]{2}{*}{ R11 } & \multirow{2}{*}{$\begin{array}{l}\text { AP-2 adaptor complex subunit } \\
\text { beta }(A P-2 \beta)\end{array}$} & \multirow[t]{2}{*}{ Transporter activity (GO:0005215) } & \multirow{2}{*}{$\begin{array}{l}\text { Involved in chlatrin-dependent } \\
\text { endocytosis }\end{array}$} & Fw: TTTCGCACATAGGGGTCG & \multirow[t]{2}{*}{$98.4 \%$} & \multirow[t]{2}{*}{$148 \mathrm{bp}$} \\
\hline & & & & Rv: TITTGGTCGATGATATGGACG & & \\
\hline \multirow[t]{3}{*}{ R12 } & \multirow{3}{*}{$\begin{array}{l}\text { Protein translocation complex } \\
\text { componenet }(\mathrm{np} / 1)\end{array}$} & Protein transporter activity (GO:0008565) & \multirow{3}{*}{$\begin{array}{l}\text { Involved in the protein progression } \\
\text { in endoplasmic reticulum }\end{array}$} & Fw: CGCTGGAACAAGAAAAATACG & \multirow[t]{3}{*}{$98.2 \%$} & \multirow[t]{3}{*}{$117 \mathrm{bp}$} \\
\hline & & $\begin{array}{l}\text { Post-translational protein targeting to } \\
\text { membrane (GO:0006620) }\end{array}$ & & Rv: ACGAACGATATGCGCCAA & & \\
\hline & & Endoplasmic reticulum (GO:0005783) & & & & \\
\hline \multirow[t]{2}{*}{$\beta-t u b$} & \multirow[t]{2}{*}{ Beta-tubulin } & Nucleotide binding (GO:0000166) & \multirow[t]{2}{*}{ Cytoskeleton } & FW: GTTCTGGACGTTGCGCATCTG & \multirow[t]{2}{*}{$97.2 \%$} & \multirow[t]{2}{*}{$110 \mathrm{bp}$} \\
\hline & & Cytoskeleton (GO:0005856) & & RV: TGATGGCCGCTTCTGACTTCC & & \\
\hline \multirow[t]{3}{*}{$a b f-B 2^{*}$} & \multirow[t]{3}{*}{ Arabinofuranosidase-B2 } & $\begin{array}{l}\text { Hydrolase activity, acting on glycosyl } \\
\text { bonds (GO:0016798) }\end{array}$ & \multirow[t]{3}{*}{ Sugar metabolism } & Fw: CGGAGCTTGGGTGAGATGGTTC & \multirow[t]{3}{*}{$103.6 \%$} & \multirow[t]{3}{*}{$112 \mathrm{bp}$} \\
\hline & & $\begin{array}{l}\text { Carbohydrate metabolic process } \\
\text { (GO:0005975) }\end{array}$ & & Rv: CGGCGGCGTTGCTAATGC & & \\
\hline & & Extracellular region (GO:0005576) & & & & \\
\hline \multirow[t]{3}{*}{$x y n C^{*}$} & \multirow[t]{3}{*}{ Xylanase C } & $\begin{array}{l}\text { Hydrolase activity, acting on glycosyl } \\
\text { bonds (GO:0016798) }\end{array}$ & \multirow[t]{3}{*}{ Sugar metabolism } & Fw: CAAATGGCGACAATGGCG & \multirow[t]{3}{*}{$94.4 \%$} & \multirow[t]{3}{*}{$104 \mathrm{bp}$} \\
\hline & & Xylan metabolic process (GO:0045493) & & Rv: TGAGTACGTGACAGTCTGTGCATTG & & \\
\hline & & Extracellular region (GO:0005576) & & & & \\
\hline
\end{tabular}

The annotation and GO terms were taken from the Talaromyces versatilis genome (basionyme Penicillium funiculosum, ADISSEO proprietary sequence, unpublished). Forward (Fw) and reverse (Rv) primer sequences used for RT-qPCR. The two genes at the bottom of the table marked with an asterisk (*) correspond to the genes of interest. 
contaminant gDNA. Amplicon sizes ranged between 70 and $200 \mathrm{bp}$. Reaction efficiency for each pair of primers was tested by the dilution series method using a mix of cDNA samples as the template. The efficiency of validated primer pairs focused around 100\% (Table 1).

\section{qPCR}

The qPCR was performed in a CFX96 Real Time PCR Detection System (Bio-Rad), using 96-well white PCR plate (Thermo) sealed with ABsolute qPCR seals (Thermo). The reaction mix consisted of $7.5 \mu \mathrm{L}$ of the DyNamo ColorFlash SYBR Green master mix (Thermo), $300 \mathrm{nM}$ of each primer and $3 \mu \mathrm{L}$ of the 1:10 diluted cDNA in a final volume of $15 \mu \mathrm{L}$. The PCR reaction cycle was: initial denaturation for $7 \mathrm{~min}$ at $95^{\circ} \mathrm{C}$, followed by 40 cycles of 10 seconds at $95^{\circ} \mathrm{C}$ and 30 seconds at $60^{\circ} \mathrm{C}$. A melting curve was performed at the end of the qPCR run, increasing the temperature in a stepwise fashion by $0.5^{\circ} \mathrm{C}$ every 5 seconds, from $65^{\circ} \mathrm{C}$ to $95^{\circ} \mathrm{C}$. Each RT-qPCR reaction was performed in technical triplicate. Two control samples were included for each primer pair tested; the no template control (NTC) and T. versatilis genomic DNA. For each sample, a ValidPrime Assay (VPA), consisting of a pair of primers that bind to a non-transcribed intergenic region identified from RNA-seq data, was also included to detect and quantify the presence of contaminating gDNA [47]. The primers for the VPA were; 5' ACCGAATGGCACCGA GTTGG 3 ' and 5'AATGGAGGAAGCGTGCCGTG 3'. As gDNA contamination rarely exceeded $1 \%$, the RTqPCR data were directly analysed using the CFX Manager software (Bio-Rad).

\section{Stability analysis}

The stability of putative reference genes was assessed using the geNorm VBA applet for Microsoft Excel [33]. geNorm allows the calculation for each reference gene of the gene expression stability value $M$, which is the average pairwise variation of a particular gene with all other control genes, the most stable genes presenting the lowest $M$ values. To determine the optimal number of genes that are required for an accurate normalization, the normalization factors $\left(\mathrm{NF}_{\mathrm{n}}\right.$, based on the geometric mean of the $n$ most stable genes) were calculated by stepwise inclusion of the most stably expressed genes. Pairwise variations $\left(\mathrm{V}_{(\mathrm{n} / \mathrm{n}+1)}\right)$ between $\mathrm{NF}_{\mathrm{n}}$ and $\mathrm{NF}_{\mathrm{n}+1}$ were then calculated to determine the effect of adding the $(n+1)^{\text {th }}$ gene. If the $\mathrm{V}_{\mathrm{n} / \mathrm{n}+1}$ is superior to the cut-off value 0.15 , the addition of the $(n+1)^{\text {th }}$ gene has a significant effect on normalization quality and should preferably be included for calculation of a reliable normalization factor.

\section{In-silico analysis of RNA-seq data}

Three RNA-seq datasets from the industrial $T$. versatilis were at our disposal (unpublished data) and were prepared from: 1) growth of the mycelium on MM for $48 \mathrm{~h}$ (reference condition); 2) transfer of the water-rinsed mycelium to MM with ball-milled wheat straw $1 \%(\mathrm{w} / \mathrm{v})$ as carbon source and sampling after $24 \mathrm{~h} ; 3$ ) direct addition of glucose at $1 \%$ final concentration to the mycelium exposed to wheat straw, and sampling after $5 \mathrm{~h}$. These RNA-seq data were used for the pre-selection of stable genes (fold change (FC) equal to one, see Additional file 2) after calculating the FC as follow: RPKM (Reads Per Kilobase of exon model per Million mapped reads) value in the sample of interest / RPKM in the reference condition, for each gene. Similarly, FC for candidate reference genes were calculated from RNA-seq data publicly available at the NCBI GEO database $[48,49]$. To identify the homologues of $T$. versatilis selected reference genes in the different fungi, a standard protein BLAST (blastp) using the amino-acid sequence from $T$. versatilis was performed against protein databases, specifying the organism. Each homologous sequence was then used for a reciprocal BLAST against the $T$. versatilis database in order to confirm the accuracy of the result. The detailed list of locus tags for each gene in every fungus is available in the Additional file 3. For each GOI in these studies, the ratio between the expression in a condition of interest and the expression in the control condition was calculated. Collected datasets were from Trichoderma reesei ([50], accession \#GSE44648), Aspergillus niger ([51], \#GSE33852), Aspergillus flavus ([52,53], \#GSE40202 and \#GSE30031), Aspergillus fumigatus (\#GSE30579), Aspergillus oryzae ([54], \#GSE18851), Aspergillus nidulans ([55], \#GSE44100), Blumeria graminis ([11], \#GSE43163), Colletotrichum graminicola ([56], \# GSE34632), Colletotrichum higginsianum ([56], \#GSE33683), Fibroporia radiculosa ([57], \#GSE35333), Magnaporthe oryzae ([58], \#GSE30327), Neurospora crassa ([55], \#GSE44100), ([59], \#GSE35227), ([60], \#GSE36719), Pyronema omphalodes ([61], \#GSE41631), Rhizoctonia solani ([12], \#GSE32577), Sordaria macrospora ([62], \#GSE33668). We also accessed unpublished data from Rhizophagus irregularis ([7], \#SRX375378 at NCBI Short Read Archive) and Leptosphaeria maculans (personal communication from T. Rouxel, INRA-Bioger, Thiverval-Grignon, France).

\section{Gene expression and statistical analyses}

Three independent cultures of $T$. versatilis were carried out to perform RNA-seq. For reference gene stability analysis by RT-qPCR, cultures of $T$. versatilis in the different conditions were performed in duplicate. qPCR assays were performed in technical triplicates. Inter-run calibrators were included in each qPCR plate. The RT-qPCR data were directly analysed using the CFX Manager software (Bio-Rad), which allows inter-run calibrations, efficiency correction, normalization with multiple reference genes and calculation of ratios with (technical) errors propagation. As advised for final calculation of $\mathrm{FC}$ values from 
biological replicates [20], statistics $($ mean \pm SD) were assessed from FC values obtained from biological replicates. Other statistical analyses were conducted by using the STATGRAPHICS Centurion 16 software. This included: the ANOVA on relative FC values (Three-level, nested ANOVA with 'genes' as the first level, 'culture conditions' as the second level and 'biological replicates' as the third level); the Hierarchical Ascendant Classification (HAC) that was performed according to the Ward method, using default parameters (standardization of the data and squared Euclidean distances); the graphical representation of box plots.

\section{Results and discussion}

Selection of candidate reference genes from $T$. versatilis RNA-seq datasets

In a preliminary study on the industrial Talaromyces versatilis strain IMI378536, RNA-seq data were generated to analyse the transcriptome of this filamentous fungus on wheat straw (unpublished data, property of ADISSEO SAS). An in silico screen for genes that showed no differential expression between glucose and wheat straw, was used to select about a hundred genes with fold-changes close to one, indicating stability of transcript levels under those conditions. From this preselection, genes were discarded because of anti-sense transcription, alternative splicing events, as well as very low expression level (RPKM below 15). The design of primers and their experimental validation by RT-qPCR were then performed on a residual list of 20 candidate genes taking care to avoid their participation in similar cellular functions to minimise the risk of co-regulation under culture conditions of interest. Finally, 12 putative reference genes were selected whose primers led to good reaction efficiency. As shown in Table 1, this selection included genes involved in intracellular signalling, vesicular trafficking, metal transport, cytoskeleton organization or protein ubiquitinylation, but quite surprisingly, it did not contain any gene implicated in the central carbon metabolism. To this list, the gene encoding $\beta$-tubulin was also included, as it is frequently used for RT-qPCR data normalization [63-67].

\section{Evaluation of the stability of candidate genes expression in $T$. versatilis cultivated under a large set of conditions}

To evaluate whether the 13 candidate genes harboured a stable transcript level and could be used as proper internal control for data normalization in RT-qPCR gene expression analysis, their transcript levels were quantified by this technique in more than 30 different conditions (Additional file 1). Growth was explored in the presence of different carbon sources (from monosaccharides to complex plant cell wall polymers), temperature, $\mathrm{pH}$ and salt stresses, as well as to carbon and nitrogen

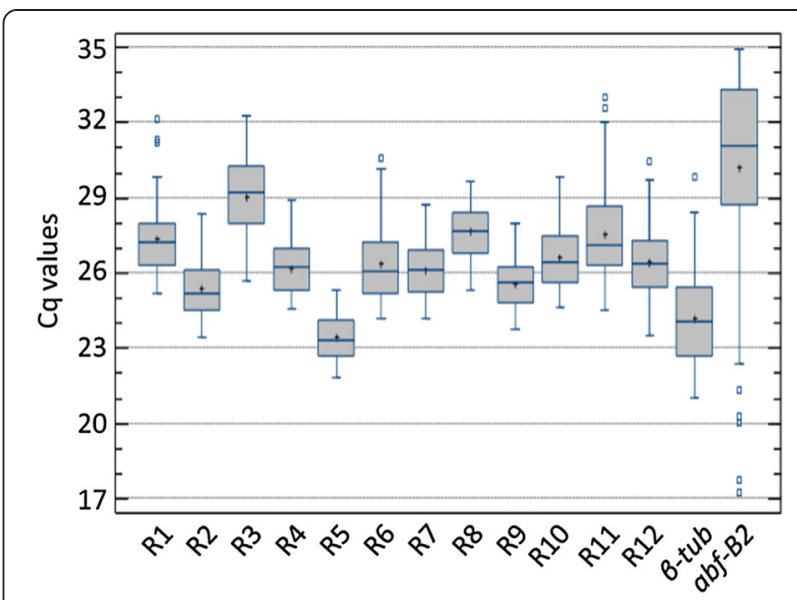

Figure 1 Distribution of the raw Cq values. For each gene, the box-plot gathered all the 66 raw Cq values obtained from the 33 duplicated culture conditions of $T$. versatilis. The lower and upper boundaries of the box (interquartile) represent the $25^{\text {th }}$ and the $75^{\text {th }}$ percentile, respectively. The line within the box corresponds to the median and the cross to the mean of the distribution, while the whiskers indicate the highest and the lowest $\mathrm{Cq}$ values, with the exception of the outliers that are represented by the squares outside the whiskers.

starvation. In addition, transcript levels of these genes were monitored during conidial germination, as this developmental process is a particularly interesting aspect of fungal biology [68-70]. The raw Cq values of the 13 genes were therefore collected under 33 conditions and compiled in the box plot (Figure 1). Most of these genes showed a compact distribution of $\mathrm{Cq}$ values, with less than $2 \mathrm{Cq}$ between the $1^{\text {st }}$ and $3^{\text {rd }}$ quartiles, indicating relatively low variation of the transcript level among the different conditions (i.e. less than 4-fold differential expression for the middle fifty). Some of them, R3 (ADA), $\mathrm{R} 11(A P-2 \beta)$ as well as the $\beta$-tub gene displayed slightly higher dispersion of their $\mathrm{Cq}$ values. The genes $\mathrm{R} 3$ and $\beta$-tub also exhibited weaker and stronger transcript levels, respectively, with approx. 100-fold differential average transcript level between each other. Besides these 2 candidates, quite similar average expression levels for the remaining 11 genes, with raw $\mathrm{Cq}$ values around 25 , were observed. This average expression level was acceptable for robust RT-qPCR assays and normalization, based on the validated reaction efficiencies and the possibility to amplify target cDNA over several logs of concentration. However, this was contrary to the notion that the transcript level of the ideal reference gene must be close to the average transcript level of the GOIs. That situation cannot occur when the GOIs present very different average transcript levels, or when a single GOI presents either potent repression or strong induction in the same study. As an example, the expression of $a b f-B 2$ encoding a GH54 $\alpha$-L-arabinofuranosidase [71], showed more than 
25 -fold relative change between the $1^{\text {st }}$ and $3^{\text {rd }}$ quartiles. The huge whiskers of $a b f-B 2$ 's box (Figure 1) reflected more than four log differential expression, and at least a 5 - $\log$ differential expression of $a b f-B 2$ between the two extreme conditions was observed.

The raw $\mathrm{Cq}$ values were transformed to quantities with efficiency correction and then analysed with the geNorm algorithm to rank the 13 candidate genes according to their $M$ value and to ascertain their expression stability over a specified set of conditions (Figure 2A). When considering the whole set of conditions that were investigated ("all conditions"), the $M$ value of these 13 genes (numbered 1 to 13 on the $\mathrm{X}$ axis in Figure 2A) was below the recommended threshold of 1.5 , even for the $\beta$-tub gene, but also R3 and R11, which ranked amongst the least stable genes in agreement with the behaviour that was reported in Figure 1. To reinforce this result, RefFinder (http://www.leonxie.com/referencegene.php), a web-based tool that integrates the currently available major computational programs (geNorm [33], Normfinder [32], BestKeeper [34] and the comparative $\Delta \mathrm{Ct}$ method [72]) was also used. As can be seen in the Additional file 4, these algorithms led to similar classifications with the notable exception of Bestkeeper that ranked R5 and $\beta$-tub as the most stable genes. Also surprisingly, geNorm from RefFinder did not lead to the same output as we got from our geNorm interface, which certainly relied on different versions of the algorithm. Similar ranking could nevertheless be observed with respect to the most stable candidates (R2, R10, R6, R12 (Figure 2A) vs.

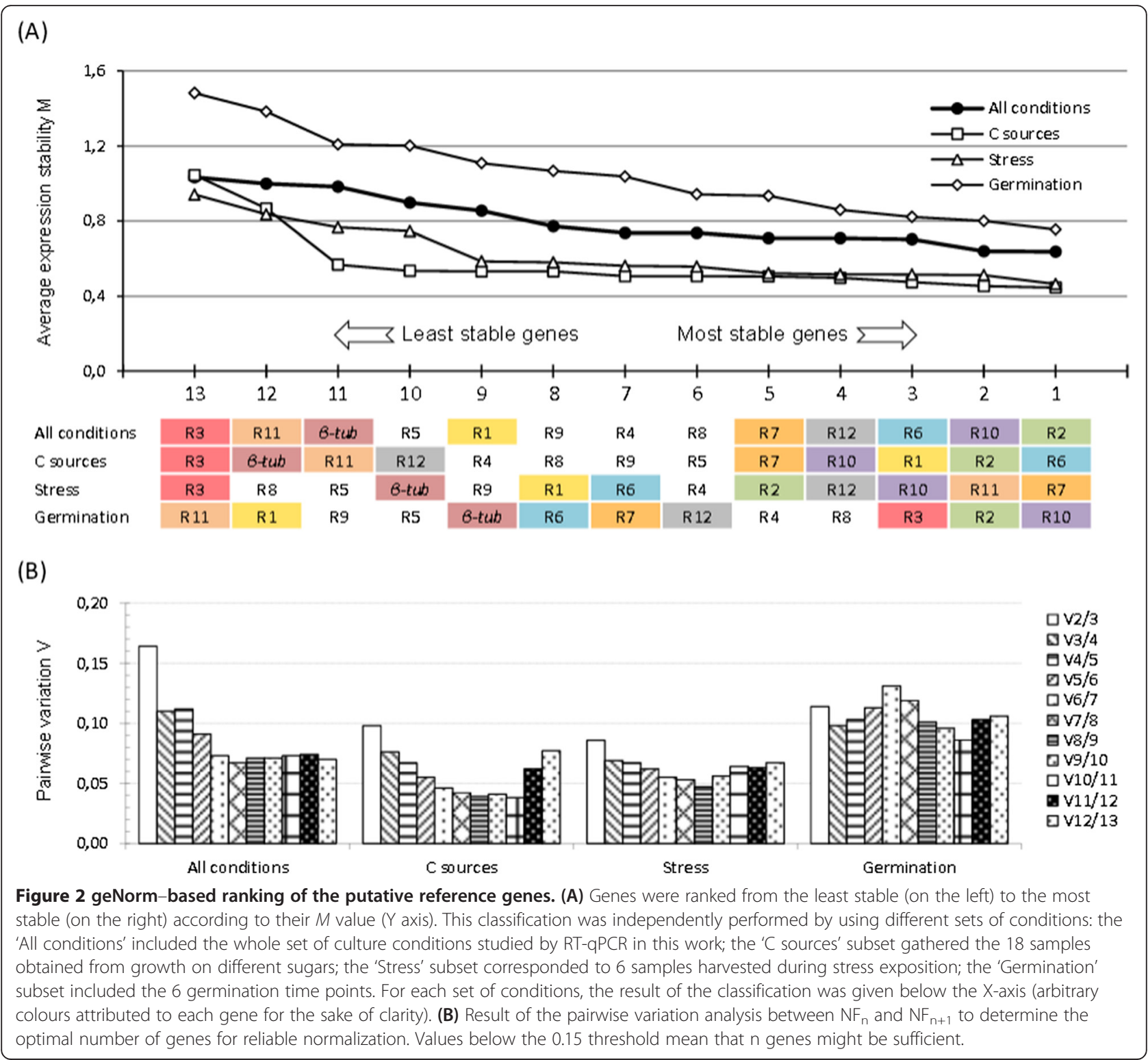


R10, R12, R2, R4 (geNorm from RefFinder)) or the least stable ones (R3, R11, $\beta$-tub, R5 (Figure 2A) vs. $\beta$-tub, R3, R11, R5 (RefFinder)). The fact that these algorithms, in particular geNorm versus NormFinder and $\Delta \mathrm{Ct}$ method, did not yield to identical results was not so surprising. As will be discussed in the next section with the classification of the genes in subsets of conditions, we indeed observed an unexpectedly uniform stability of the candidate reference genes, suggesting that they are all almost as good as each other. This is most likely the reason why these different algorithms could not propose clear-cut, identical classifications of these genes.

Still using geNorm, the optimal number of reference genes required for accurate normalization in the "all conditions" set (Figure 2B) was evaluated. Vandesompele and coworkers [33] recommended a cut-off value at 0.15 for the pairwise variation value $\left(\mathrm{V}_{\mathrm{n} /(\mathrm{n}+1)}\right)$, below which the inclusion of an additional gene does not result in a significant improvement of the normalization. According to this criterion, the $V_{2 / 3}$ and $V_{3 / 4}$ values indicated that three genes, i.e. R2 ( $u b c B), \mathrm{R} 10$ (sac7) and R6 (psm1), were sufficient for accurate normalization of transcript levels in any of the samples examined.

Evaluating gene expression stability in subsets of conditions The stability of transcript levels was similarly analysed in subsets of selected conditions, i.e. samples from mycelium grown in different carbon sources ('C $\mathrm{C}$ sources' subset), samples from mycelium exposed to different stress conditions ('Stress' subset) and samples harvested during conidial germination ('Germination' subset) (Figure 2A). While R1, R11 and R3 were amongst the least stable genes when analysing the whole set of conditions, they classified amongst the 3 best genes in the ' $C$ sources', 'Stress' and 'Germination' subsets, respectively. This reorganisation of the ranking, when conditions changed, could be explained by the uniformly stable transcript levels from these genes, particularly in the ' $\mathrm{C}$ sources' and 'Stress' subsets, which led to low and stable $M$ values for 11 and 9 genes amongst the 13 candidates, respectively. This remarkable stability for most of the genes was also supported by the pairwise variation values (Figure $2 \mathrm{~B}$ ), which indicated that only two genes could ultimately be used for robust normalization in these ' $\mathrm{C}$-sources' (R6 and R2), 'Stress' (R7 and R11) and 'Germination' (R10 and R2) subsets. In the first two subsets, the stepwise inclusion of reference genes led to continuous decrease of the $\mathrm{V}$ value, until the inclusion of the least stable genes reversed the tendency. These values were nevertheless always below the 0.15 cut-off value, confirming the extreme stability of transcript levels from these genes.

In the context of conidial germination, the identification of reliable reference genes was first challenged by the difficulty of producing good quality RNA samples. The influence of RNA quality on reproducibility of measured transcript levels was recently reviewed [73,74], highlighting that the process of normalization does not completely resolve the bias of using compromised RNA quality on the final results. In our hands, only the use of the TriZol reagent secured the mRNA quality standard required for reliable RT-qPCR analysis. This technical prerequisite being fulfilled, the analysis of $\mathrm{Cq}$ values in this 'Germination' subset showed that the $M$ values increased more rapidly than for ' $\mathrm{C}$-sources' and 'Stress' subsets, indicating higher expression variability of the genes. This was further illustrated by a hierarchical ANOVA of the relative transcript level data (Figure 3), where it was observed that 70 to $80 \%$ of the variation for the 'C-sources' and 'Stress' subsets took place at the level of the biological replicates (Figure 3A \& B), supporting the extremely low variation between genes as well as the low influence of conditions on the transcript levels. In contrast, the variation observed between genes strongly increased in the 'Germination' subset, to reach about $50 \%$ of total variation (Figure $3 \mathrm{C}$ ), which was particularly emphasized with genes such as R6 and R11 that exhibited a strong bias (higher expression and activation during germination). The genes R10, R2 and R3, which were classified by geNorm as the best reference genes in this specific subset, were used for normalization (see below, $\left.\mathrm{NF}_{(\mathrm{R} 10, \mathrm{R} 2, \mathrm{R} 3)}\right)$ and confirmed that R6 and R11 were induced respectively by 6 and 12-fold, 6 hours after the beginning of the germination process (data not shown).

\section{Robust normalization using the geometric mean of a minimal number of these candidate reference genes}

In order to minimise the risk of bias from using a single gene as a reference, it is preferable to normalize using the geometric mean of multiple reference genes, as it was proposed previously [33]. This normalization bias, i.e. under- or over-estimation of the normalised expression value of GOIs, or how the use of different reference genes can impact biological conclusions, was illustrated by studying the transcript level of two relevant genes of T. versatilis, namely abf-B2 encoding a GH54 arabinofuranosidase [71] and $x y n C$ encoding a GH11 xylanase [75], under three different culture conditions (Figure 4A). Using a theoretically ideal normalization factor $\left(\mathrm{NF}_{(\mathrm{R} 2}\right.$, R10, R6), geometric mean of R2, R10 and R6 transcript levels), it was found that the transcript level of $a b f-B 2$ increased by 2.2 and 32-fold upon transfer from glucose to thio-gentiobiose and arbocel, respectively, whereas the transfer to $\mathrm{C}$-starved medium did not cause any significant change. Different regulatory patterns were obtained using single reference genes for normalization. The use of R3, the worst gene according to geNorm classification, led to no-significant change of $a b f-B 2$ 


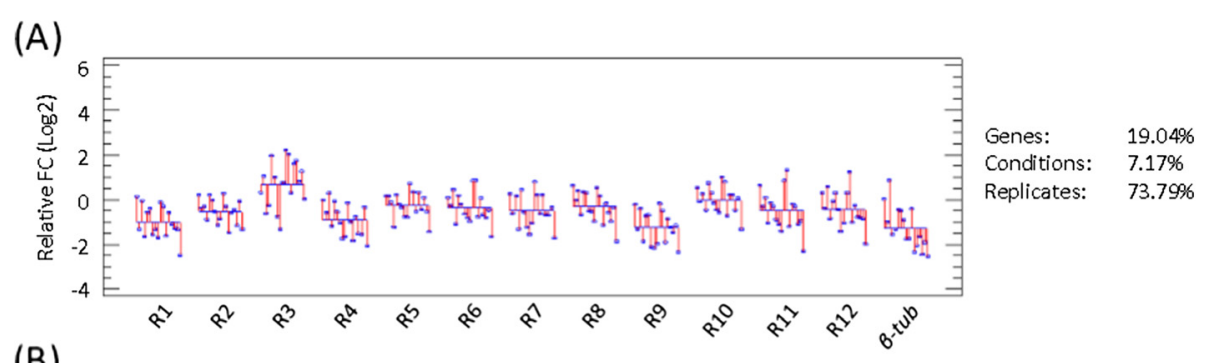

(B)

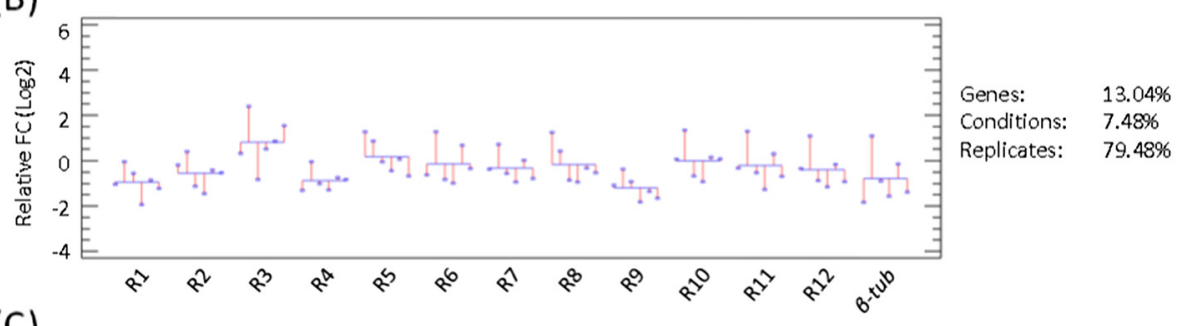

(C)

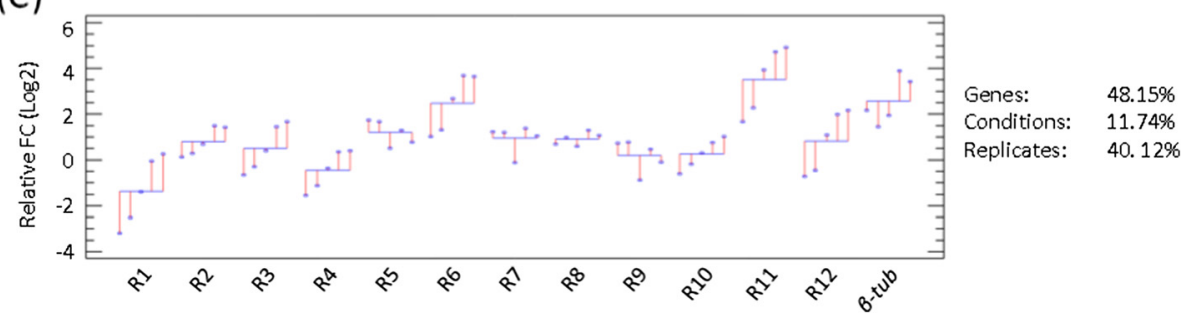

Figure 3 Hierarchical ANOVA of the putative reference genes. Three-level, nested ANOVA with 'genes' as the first level, 'culture conditions' as the second level and 'biological replicates' as the third level. As in Figure 2, this ANOVA was carried out using different sets of conditions: 'C sources' subset (A); 'Stress' subset (B); 'Germination' subset (C). Left graph: relative expression values (Log (base 2)) as a function of the different conditions for the different genes, taking as the control conditions the glucose sample (A \& B subsets) and the T0 time-point for spore germination (C subset). Two values were used for each condition (i.e. duplicated experiment). Right panel: partitioning of the variance into the three levels (in \%).

transcript level upon transfer to thio-gentiobiose, slightly over-estimated induction on arbocel (64-fold), and indicated that this gene was repressed by 3 -fold upon C-starvation. The use of $\beta$-tub also modified the expression pattern but in contrast to R3, it allowed concluding that $a b f-B 2$ was induced by 9 and 7 -fold upon transfer to thio-gentiobiose and C-starvation, respectively. Similar conclusions could be drawn by analysing $x y n C$. While transcripts levels of this gene were not significantly affected upon transfer to thio-gentiobiose or C-starved medium when using $\mathrm{NF}_{(\mathrm{R} 2, \mathrm{R} 10, \mathrm{R} 6) \text {, the use of }}$ R3 allowed concluding that this gene is slightly repressed upon transfer to these conditions, while the use of $\beta$-tub would conclude on clear induction by 5 - and 12-fold, respectively. Only in a few circumstances (e.g. arbocel sample in this example), the use of single genes for normalization may lead to similar fold change values whatever the reference gene used. To better prove the importance of averaging several, functionally unrelated candidate reference genes to gain a significant reduction of the normalization bias, we gathered together the three worst candidate genes, including $\mathrm{R} 3$, to calculate the normalization factor $\mathrm{NF}_{(\mathrm{R} 5, \mathrm{R} 11, \mathrm{R} 3) \text {. Fold change values }}$ reported in Figure 4A clearly showed that the use of NF (R2, R10, R6) and $\mathrm{NF}_{(\mathrm{R} 5, \mathrm{R} 11, \mathrm{R} 3)}$ lead to almost identical results. This result discredited the use of single genes such as R3 or $\beta$-tub (even if their use could, by chance, lead to fairly good conclusions (e.g. arbocel condition in this figure)), but it illustrated the strength of geometric averaging multiple genes to smooth individual, sometimes important variations of the transcript level of single reference genes. This is a particularly relevant aspect to avoid incorrect biological interpretation of gene regulation, particularly if the biological significance of subtle differences in fold-changes values is to be considered.

These preliminary, illustrative results prompted us to extend this analysis in our specific set of conditions to obtain a better idea of the frequency and extent of under- or over-estimation of normalized expression value of GOIs by using different reference genes. Also, different sub-optimal combinations of reference genes were challenged by evaluating the normalization bias that might result from their use. We studied here normalization factors (NF) calculated from combinations 


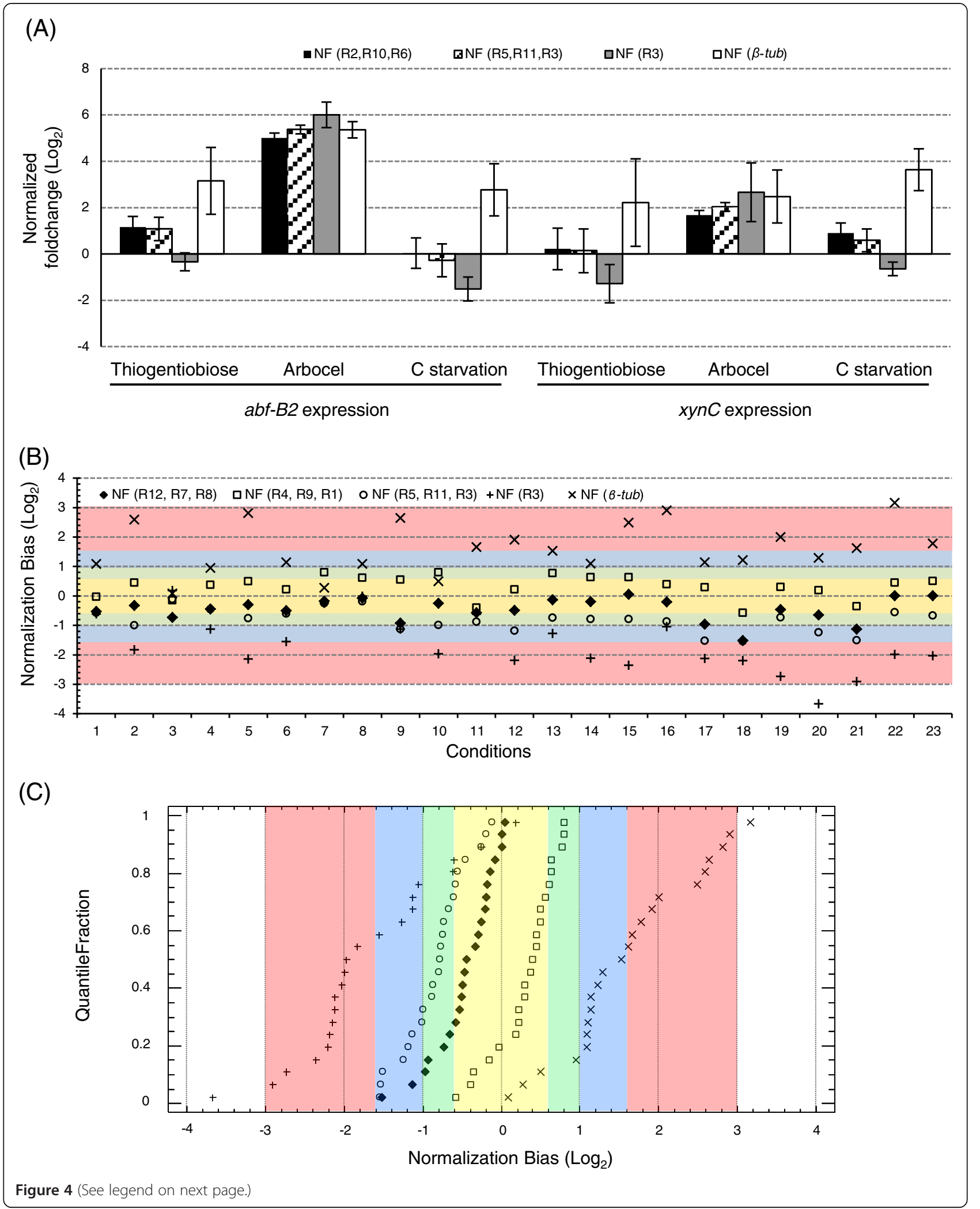


(See figure on previous page.)

Figure 4 Normalization bias analysis according to reference genes selection. (A) Example of normalized transcript levels of $a b f-B 2$ and $x y n C$ under different culture conditions (Thio-gentiobiose, Arbocel and $C$ starvation samples) using 4 different Normalization Factors (NFs): NF(R2, R10, R6), $N F_{(R 5, R 11, R 3)} N F_{(R 3)}$ and $N F_{(\beta-t u b)}$. $L o g$ (base 2) of $F C$ values on the $Y$ axis (mean $\pm S D, n=2$ in this experiment) using glucose as the calibrator sample. (B) Comparison of $\mathrm{NF}_{(\mathrm{R} 2, \mathrm{R} 10, \mathrm{R} 6)}$ to NF calculated from less stable genes, as well as from single genes such as R3 and $\beta$-tub. For each condition of interest ( $X$ axis, see Additional file 1), we calculated a normalization bias (i.e. under- or over-estimation of the normalised expression value of GOIs) as the ratio between the theoretically best $\mathrm{NF}(\mathrm{NF}(\mathrm{R} 2, \mathrm{R} 10$, R6) as determined from geNorm classification by using the entire set of conditions) and NF calculated from other combinations of reference genes. Log (base 2) of the normalization bias is represented on the $Y$ axis. Yellow zone: less than 1.5 fold bias; Green zone: 1.5-2 fold bias; Blue zone: $2-3$ fold bias; Red zone: $3-8$ fold bias. (C) Quantile plot of the normalization bias values for each NF. The normalization bias $\left(\log _{(\text {base 2) }}\right)$ is represented on the $X$ axis and the same colour code used in (B) was applied. The quantile fractions are represented on the $Y$ axis. ()$_{(R 12, R 7, R 8),}(\square) N F_{(R 4, R 9, R 1),}(O) N F_{(R 5, R 11, R 3),}(+) N F_{(R 3)}$ and $(X) N F_{(\beta-t u b)}$.

of three candidates, from less well ranked genes $\left(\mathrm{NF}_{(\mathrm{R} 12,}\right.$ $\mathrm{R} 7, \mathrm{R} 8), \mathrm{NF}_{(\mathrm{R} 4, \mathrm{R} 9, \mathrm{R} 1)}$ and $\mathrm{NF}_{(\mathrm{R} 5, \mathrm{R} 11, \mathrm{R} 3)}$, respectively). The normalization bias was calculated in each condition as the ratio between a given normalization factor and the theoretically ideal one $\left(\mathrm{NF}_{(\mathrm{R} 10, \mathrm{R} 2, \mathrm{R} 6)}\right)$. The use of the $\beta$-tub gene alone, which ranked amongst the least stable genes (Figure 2A), altered the quality of the normalization with over-estimation in most of the conditions that were studied (Figure 4B, crosses in the upper blue and red zones). This effect was emphasized in the quantile plot (Figure 4C), as an unbiased response (i.e. less than 1.5-fold bias) was observed in less than $10 \%$ of the conditions, while $50 \%$ of the samples showed more than 3 -fold overestimation. Conversely, the use of R3 alone resulted in 3.0-8.0-fold under-estimation in more than half of the samples tested in our study (Figure $4 \mathrm{~B} \& \mathrm{C}$, lower red zone). We could observe a significant reduction of the normalization bias by averaging $\mathrm{R} 3$ in $\left.\mathrm{NF}_{(\mathrm{R} 5}, \mathrm{R} 11, \mathrm{R} 3\right)$, which led to a clear shift of the curve towards the central zone, with more than $70 \%$ of the conditions exhibiting less than 2 -fold bias while the remaining 6 samples did not exceed 3.0-fold down-estimation (conditions \#12, 17, 20 and 21 from the $\mathrm{NF}_{(\mathrm{R} 5, \mathrm{R} 11, \mathrm{R} 3)}$ series, blue zone), confirming the results shown on Figure 4A. In most cases, the use of NFs that were calculated from multiple genes led to a minimal normalization bias (yellow-green zone), which was a clear illustration of the prime importance of normalising by the geometric averaging of multiple genes to minimize the bias during normalization of GOIs [33].

\section{Expression data collection from phylogenetically distant filamentous fungi}

To demonstrate the suitability of some of the 12 putative reference genes for RT-qPCR analysis in fungi, RNA-seq based transcriptomic datasets from 18 phylogenetically distant filamentous fungi were interrogated, exploiting web resources such as the GEO portal $[48,49]$. These datasets covered model fungi [55,59-62], biotechnologically important organisms [50,51,54], agronomically relevant fungi such as symbiotic organisms or plant pathogens ([8,11,12,47-49] and personal communications), and human pathogens $[52,53]$. This collection corresponded to
90 independent datasets, most of them in triplicates and harvested from a broad variety of experimental conditions, e.g. exposure to stress, nutritional source utilisation, fungihost interactions or development stages (see Additional file 5 for further details). To further strengthen this analysis, genes were included that have been evaluated for their use in Aspergillus niger [35] and Trichoderma reesei [36]. The 12 genes selected here are henceforth referred to as the ' $R$ series' and the additional reference genes were termed ' $\mathrm{C}$ series' and contained the actin $(\mathrm{C} 1, a c t)$, aminopeptidase $\mathrm{C}(\mathrm{C} 2$, aps $\mathrm{C})$, cytochrome $\mathrm{C}$ oxidase subunit $\mathrm{V}$ $(\mathrm{C} 3, \operatorname{coxV})$, glyceraldehyde-3-phosphate dehydrogenase $(C 4$, gapdh), glucokinase $(C 5$, glkA), glucose-6-phosphate dehydrogenase (C6, g6 $p d h)$, isocitrate dehydrogenase precursor $(\mathrm{C} 7, i c d A)$, phosphofructokinase $(\mathrm{C} 8, p f k A)$, phosphoglucose isomerase $(C 9$, pgiA $)$, a secretion associated GTP-binding protein $(\mathrm{C} 10$, sarA), and the translation elongation factor a1 $(\mathrm{C} 11$, ted1a). The $\beta$-tub gene $(\mathrm{C} 12)$, which was not part of $A$. niger and $T$. reesei studies, was also included in this study as it has been evaluated amongst other putative reference genes in similar studies ([38-43] and Additional file 6). Finally, 4 further genes were added that were homologous to $S$. cerevisiae ALG9 (Sc1), TAF10 (Sc2), TFC1 (Sc3) and UBC6 (Sc4), which have been previously validated as good reference genes in this yeast [76]. For every gene, in each specific study, fold changes (FC) were calculated as the ratio between the expression in a condition of interest and the expression in the control condition that was designed in this specific study.

Changes in transcript levels in the different conditions for the different fungi, were used to generate a heat map (Figure 5). None of the genes from the ' $\mathrm{C}$ series' was stable in the two $T$. versatilis conditions and explains why they were not pre-selected in this study. Also, in RNA seq data collected from $R$. irregularis, $P$. omphalodes, $R$. solani, F. radiculosa, $M$. oryzae and $A$. nidulans, almost all the candidate genes and those from the ' $C$ series' exhibited good expression stability, as indicated by the generalized greenish colour. Half of those genes had FC values lower than 1.2 (data not shown) and FC values almost never higher than 2. During the early stages of plant infection 


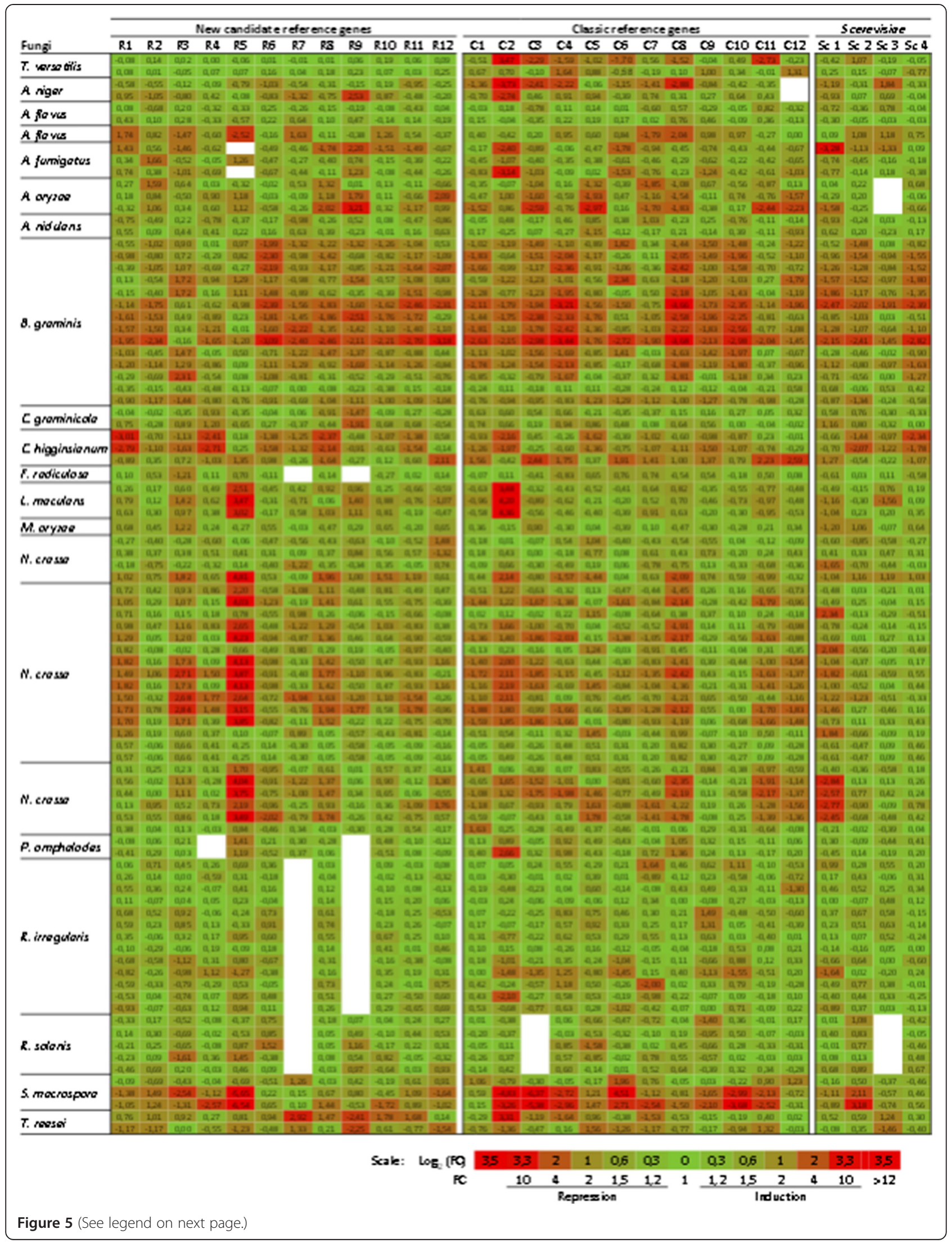


(See figure on previous page.)

Figure 5 Heat map of RNA-seq based expression data of putative reference genes, collected from 18 phylogenetically distant fungi. For each RNA-seq dataset (study), we calculated for each gene fold changes (FC) as the ratio between the expression in a condition of interest and the expression in the condition that was defined as the control in this study. Each line represents a condition of interest, each column a gene of interest (corresponding names of the genes are given in Figure 6). Genes have been distributed in three groups: the 'R series' that corresponds to 12 candidate reference genes pre-selected from $T$. versatilis data; the ' $C$ series' that corresponds to more classic reference genes previously used in most of gene expression studies, including for filamentous fungi; and the 'Sc series' that corresponds to genes homologous to S. cerevisiae genes, which were previously validated as promising reference genes in this yeast species. Numbers reported in the heat map correspond to $\log ($ (base 2) of FC values. Colour scale and correspondences between Log (base 2) and FC values are indicated in the legend (green colour set for a fold-change of $1\left(\log _{2}=0\right)$; red colour arbitrary set for differential expression equal or higher than $12\left(\left|\log _{2}\right| \geq 3,5\right)$. Empty cells: data not available.

by B. graminis, extensive transcriptomic changes were observed for most of the genes. A similar situation was observed during different development stages of S. macrospora, where most of the reference genes were either down- or up-regulated. These two datasets strengthened the conclusion that even the best reference genes will never escape sporadic differential expression, so that validation of their stability is highly recommended prior to their use for normalization in each new project. When focused on the different Aspergillus and Neurospora species, visual inspection of the heat map suggested that genes from the ' $\mathrm{R}$ series' were slightly more stable. This was confirmed when pooling and analysing together all $\mathrm{FC}$ values from the ' $\mathrm{R}$ ' and ' $\mathrm{C}$ ' series, respectively, as the median and interquartile of these two gene subsets indicated a clear tendency to down regulation of the 'C series' (results not shown). A striking feature within this ' $\mathrm{R}$ series' was nevertheless the R5 (Cu-ATPase) gene that was strongly regulated under a few conditions, particularly in N. crassa exposed to Avicel or carbon starvation. This latter observation was however specific to $N$. crassa, as this gene was perfectly stable in $T$. versatilis mycelium similarly exposed to this carbon source or to $\mathrm{C}$ starvation (not shown). Finally, the fungal genes homologous to yeast Sc3 (TFC1) and Sc4 (UBC6) exhibited relatively stable transcript levels in most of the filamentous fungi and conditions of interest, with the notable exception of B. graminis during plant infection as already mentioned above. In contrast, Sc1 (ALG9) exhibited much higher fluctuations of FC values.

\section{Global analysis of reference genes stability in filamentous fungi}

To identify the most relevant reference genes among the whole ' $\mathrm{R}$ ' and ' $\mathrm{C}$ ' series, the $92 \mathrm{FC}$ values were pooled for each gene independently (Figure 6). When looking at the median and interquartile, which are robust statistical parameters especially for small samples that are not normally distributed, the most promising genes should present a median close to zero and a compact interquartile, indicating no differential expression and low variation, respectively. Remarkably, R2 $(u b c B)$, which was identified by geNorm as the best reference gene for $T$. versatilis, exhibited such requirements with a median close to zero and FC values that did not exceed 1.3 (repression or induction) in half of the conditions collected in this study. In contrast, the R5 gene (Cu-ATPase) exhibited a very strong bias towards overexpression and a much higher variation in FC values, even when removing outliers that mostly fitted with $N$. crassa samples exposed to cellulose.

To search for groups of genes presenting similar behaviour, a cluster analysis (HAC) was conducted, using the median and the interquartile as variables (Additional file 7). Moderate partitioning led to the identification of 5 classes, highlighted in the interquartile versus median scatter plot (Figure 7). The best class (red), with its centroid having a median at zero and the lowest variation, contained three of the new candidates $(\mathrm{R} 2(u b c B)$ and R10 ( $\operatorname{sac} 7)$, previously designated as the best reference genes for T. vesatilis, and R4 (fis1)), C10 (sarA) that encodes a secretion-associated GTP-binding protein that was already identified as a good reference gene [35,36], and two genes homologous to S. cerevisiae TFC1 (Sc3) and UBC6 ( $\mathrm{Sc} 4)$. In contrast, the orange class, which had the largest interquartile of the study indicative of poor stability and higher probability of differential expression, included C8 (pfk), C4 (gapdh) and C2 (apsC) genes. In between, the green category contained several classic reference genes such as C1 (act) and C5 (glk), which presented fairly centred medians but showed the highest variability within this class. Other frequently used reference genes such as C12 ( $\beta$-tub), C11 (tef1) and C6 $(g 6 p d h)$ were categorised in a less promising group that presented a reasonable level of variability but a tendency towards down-regulation (class 4, blue). Finally, R5 (Cu-ATPase) and R3 (ADA), which classified amongst the least stable genes in $T$. versatilis samples, confirmed their low stability in other filamentous fungi and a clear bias to overexpression (class 5 , violet).

Even though genes in the red class could be considered as a very promising set of reference genes for normalization purposes in fungi, they too may present unexpected regulatory changes in specific contexts. An interesting case-study was indeed found in this work with two of these most promising reference genes, i.e. R4 (fis1) and Sc4 (UBC6), which were strongly down-regulated in $C$. higginsianum 


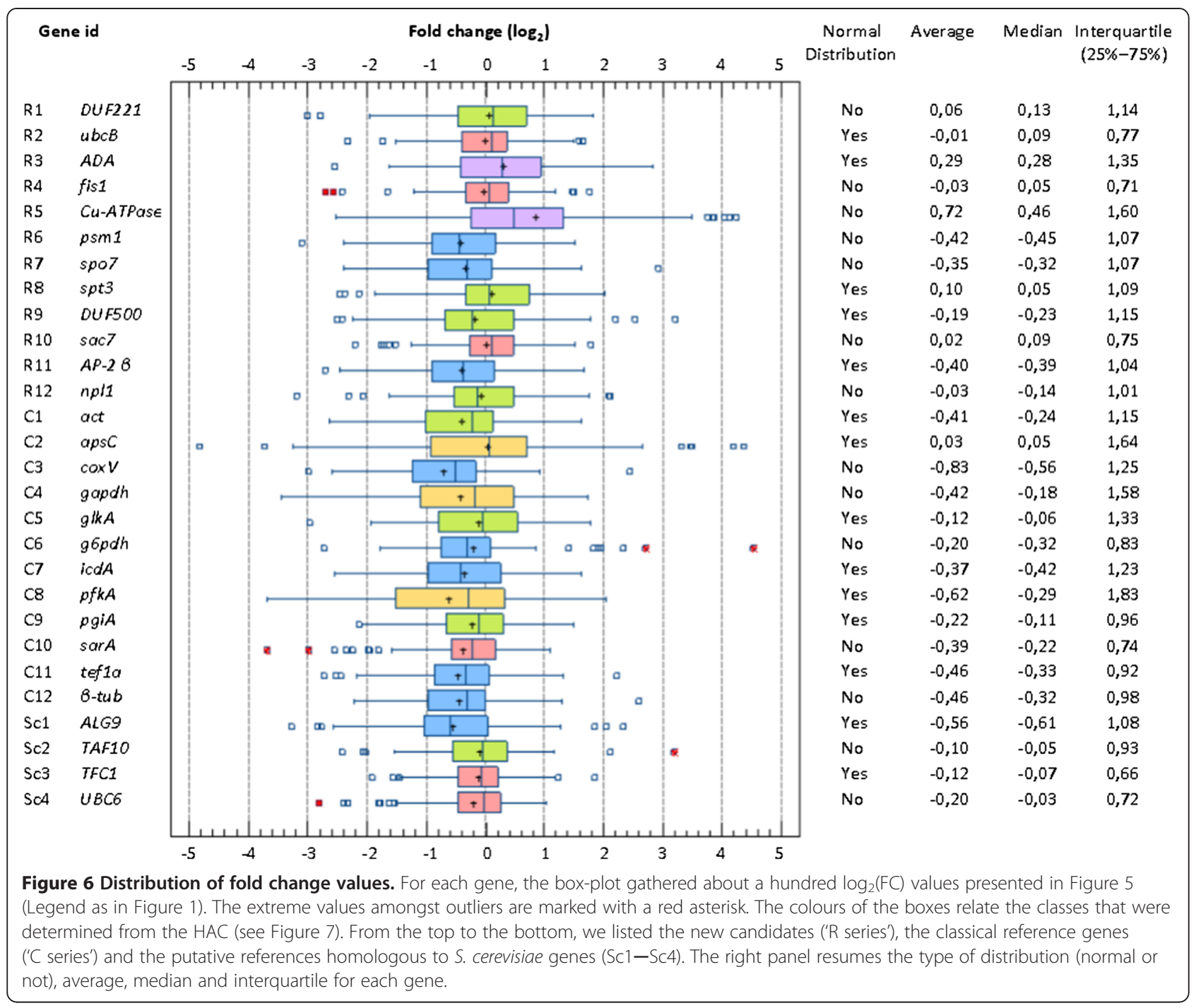

during infection phases of Arabidopsis thaliana (Figure 5). Moreover, although a reference gene is certified in an organism of interest, it does not preclude extremely different regulatory patterns in phylogenetically distant organisms exposed to strictly similar conditions. It was found for example that R5 ( $\mathrm{Cu}$-ATPase) was stable in $T$. versatilis exposed to Avicel or $C$ starvation (data not shown), while it was strongly activated by these environmental conditions in $N$. crassa. Such examples clearly emphasise that validation experiments are mandatory to avoid the drawbacks of using inappropriate reference genes $[77,78]$. The second important point that should be stressed is the possible coregulation of selected reference genes. While apparently linked to GTP, R10 (sac7) and C10 (sarA) seem to be implicated in independent functions, i.e. signal transduction and secretion, respectively. Unfortunately, this is not the case for $\mathrm{R} 2(u b c B$, Ubiquitin-protein ligase activity) and Sc4 (UBC6, ER-associated protein catabolic process), which belong to a similar functional category and hence may show undesirable co-regulation. Therefore, the use of both of them as references genes should be discouraged, although both could be evaluated.

It is unlikely that expression of most of these promising reference genes will be found to be unstable simultaneously in future projects. If this was the case, it will require identifying and validating new genes. Transcriptomic data obtained from distant organisms studied under comparable conditions, or from the organism of interest cultivated in conditions as diverse as possible, could be collected. This strategy turned out to be successful in our hands for pre-selection of appropriate reference genes, even from a very limited set of transcriptomic data as starting material. The automated identification of suitable reference genes by the use of tools such as RefGenes [30] might be useful, taking care to focus on functionally unrelated candidates, provided 


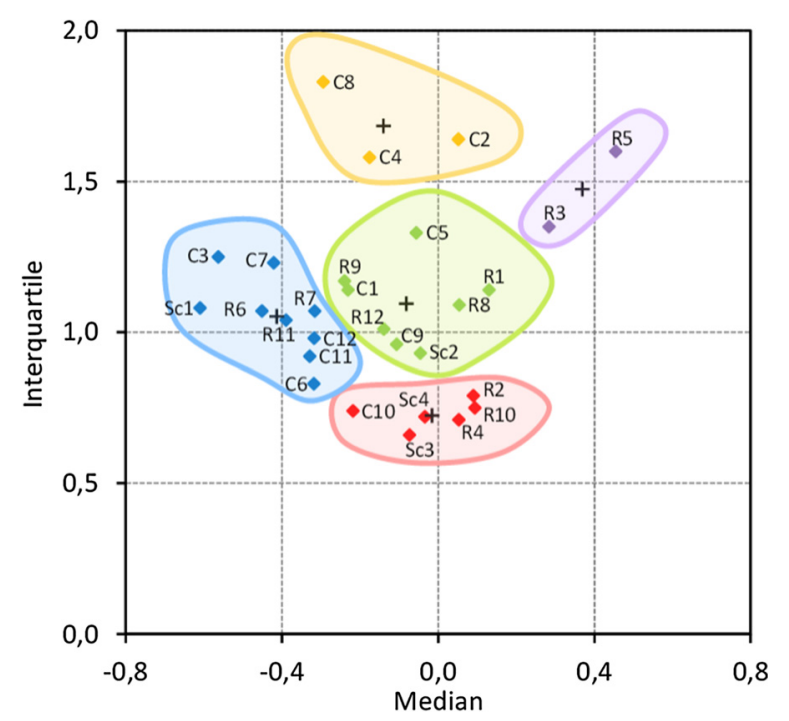

Figure 7 Classification of the reference genes according to their median and interquartile. Scatter plot of the interquartile versus median. The clusters that were obtained by hierarchical classification (HAC, see Additional file 7) are circled with different colours. The black crosses indicate the centroid of each cluster.

that transcriptomic data that are targeted by this tool are generalised to all published datasets, including those that have been produced from filamentous fungi.

\section{Conclusions}

Starting with a restricted set of 3 RNA-seq based transcriptomic datasets from $T$. versatilis cultivated under extremely different growth conditions, a list of 12 stable genes that belong to different functional classes was selected. The stability of transcript levels in more than thirty conditions of interest such as varied nutritional sources, stress exposure or time course analysis of conidial germination was examined. Three genes, R2 $(u b c B), \mathrm{R} 10(\operatorname{sac} 7)$ and R6 (psm1), were certified as the best reference genes for accurate normalization of expression levels in T. versatilis. Ideally, the optimal number of genes relies on the stepwise inclusion of additional reference genes until the time when this supplementary gene may not improve, nor worsen the normalization factor [33]. The overall good stability of the 12 candidates selected allowed us to show that any combination of 3 of them resulted in very similar normalized fold-change values and minimal normalization bias, even with the least stable genes on the list.

The main challenge concerning reference gene-based normalization is the circular problem in evaluating the expression stability of the candidate reference genes if no reliable normalization method is available [32]. To overcome this problem, transcriptomics can be used for pre-selection of unregulated candidates, choosing functionally unrelated genes to avoid co-regulated candidates, and identifying the best genes with the help of specific algorithms such as geNorm [33]. We clearly observed that normalization by single non-validated genes, i.e. $\beta$-tub or one of the least stable candidate genes of the list, introduced 3 to 8 -fold normalization bias in more than half of the conditions investigated in this study. This could lead to inaccurate biological interpretation of gene regulation, particularly if the biological significance of subtle differences in fold-changes values of GOIs is to be considered.

Beyond their robustness in $T$. versatilis, the suitability of these reference genes for RT-qPCR analysis within the filamentous fungal kingdom was assessed, by collecting RNA-seq based transcriptomic data from 18 phylogenetically distant fungal species. The representative set of organisms and experimental conditions that was collected, confirmed that most of the classic "housekeeping" genes such as $g 6 p d h, \beta-t u b$ and act did not appear as the most stable genes, even if the latter has been classified among the best reference genes in few specific studies [35,41]. Other genes involved in central metabolism, e.g. pfk, gapdh, aspC or $g l k$, also showed the highest occurrence of significant down- or up-regulation, which, together with their probable risk of co-regulation, strongly discouraged their further use as reference gene for RT-qPCR gene expression analysis.

The most promising group of six reference genes included $u b c B$ (ubiquitin carrier protein), $s a c 7$ (Rho GTPase activator), fis1 (mitochondrial membrane fission protein), sarA (secretion associated GTP-binding protein), and two genes homologous to S. cerevisiae TFC1 and UBC6 (proteins involved in transcription initiation on Pol III promoters and ER-associated protein catabolic process, respectively). Four of these six genes - sac7, fis1, sarA and UBC6 - presented a non-normal distribution with rare cases of strong differential expression in these RNA-seq conditions. There is no single universal gene that exhibits stable expression levels in any sample and/or organism of interest [33]. The need for systematic validation of the stability of transcript levels from these reference genes in future studies is therefore warranted.

\section{Ethics}

Material and experiments carried out in the frame of this article did not require any ethics approval.

\section{Additional files}

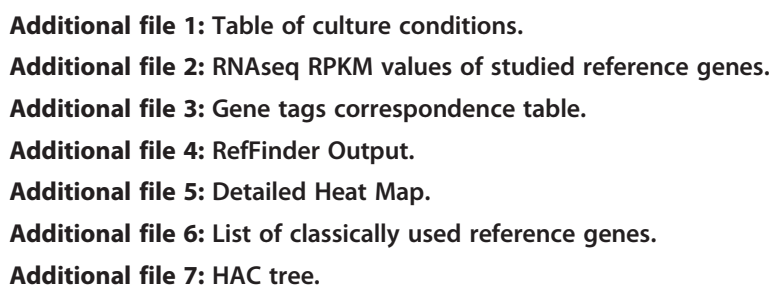




\section{Competing interests}

The authors declare that they have no competing interests.

\section{Authors' contributions}

$A L$, JMF and JLP conceived the study. AL carried out the cultures, samples treatment and Rt-qPCR analysis. AL and JLP analysed the results. AL, JMF and JLP wrote the manuscript and all authors approved the final version.

\section{Acknowledgements}

This work was supported in part by the CINABio-Adisseo (Adisseo SAS, Antony, France) to JMF \& JLP and by CIFRE, grant number: 1558/2010 to AL. We are grateful to Christophe Roux (LRSV, Toulouse, France) and Thierry Rouxel (INRA-Bioger, Thiverval-Grignon, France) for providing access to their unpublished RNA-seq data from Rhizophagus irregularis and Leptosphaeria maculans, respectively, Jolanda Van Munster (University of Nottingham, UK) for providing RNA-seq data analysis from T. reesei and A. niger, and David Archer, Steve Pullan, Stéphane Delmas and Martin Blyth (University of Nottingham, UK ) for contribution in the production of T. versatilis RNA-seq results (unpublished results). We also thank David Archer (University of Nottingham, UK) for scientific support during this work and proofreading of the manuscript.

\section{Author details}

'Université de Toulouse; INSA, UPS, INP; LISBP, 135 Avenue de Rangueil, F-31077 Toulouse, France. ${ }^{2}$ INRA, UMR792 Ingénierie des Systèmes Biologiques et des Procédés, F-31400 Toulouse, France. ${ }^{3}$ CNRS, UMR5504, F-31400 Toulouse, France. ${ }^{4}$ Cinabio-Adisseo France S.A.S., 135 Avenue de Rangueil, 31077 Toulouse, France.

\section{Received: 25 April 2014 Accepted: 7 January 2015} Published online: 14 February 2015

\section{References}

1. Archer DB, Connerton IF, MacKenzie DA. Filamentous fungi for production of food additives and processing aids. Adv Biochem Eng Biotechnol. 2008;111:99-147

2. De Vries RP. Regulation of Aspergillus genes encoding plant cell wall polysaccharide-degrading enzymes; relevance for industrial production. Appl Microbiol Biotechnol. 2003;61:10-20.

3. Floudas D, Binder M, Riley R, Barry K, Blanchette RA, Henrissat B, et al. The paleozoic origin of enzymatic lignin decomposition reconstructed from 31 fungal genomes. Science. 2012;336:1715-9.

4. Wiemann P, Keller NP. Strategies for mining fungal natural products. J Ind Microbiol Biotechnol. 2014;41:301-13.

5. Brakhage AA, Schroeckh V. Fungal secondary metabolites - strategies to activate silent gene clusters. Fungal Genet Biol. 2011;48:15-22.

6. Houbraken J, de Vries RP, Samson RA. Modern taxonomy of biotechnologically important Aspergillus and Penicillium species. Adv Appl Microbiol. 2014;86:199-249.

7. Blackwell M. The fungi: 1, 2, 3 ... 5.1 million species? Am J Bot. 2011;98:426-38.

8. Tisserant E, Malbreil M, Kuo A, Kohler A, Symeonidi A, Balestrini R, et al. Genome of an arbuscular mycorrhizal fungus provides insight into the oldest plant symbiosis. Proc Natl Acad Sci. 2013;110(50):20117-22.

9. Schmidt SM, Panstruga R. Pathogenomics of fungal plant parasites: what have we learnt about pathogenesis? Curr Opin Plant Biol. 2011;14(4):392-9.

10. Rouxel T, Grandaubert J, Hane JK, Hoede C, van de Wouw AP, Couloux A, et al. Effector diversification within compartments of the Leptosphaeria maculans genome affected by repeat-induced point mutations. Nat Commun. 2011:2:202.

11. Hacquard S, Kracher B, Maekawa T, Vernaldi S, Schulze-Lefert P, Themaat E. Mosaic genome structure of the barley powdery mildew pathogen and conservation of transcriptional programs in divergent hosts. Proc Natl Acad Sci U S A. 2013;110(24):E2219-28.

12. Zheng $A$, Lin $R$, Zhang $D$, Qin $P, X u L$, Ai $P$, et al. The evolution and pathogenic mechanisms of the rice sheath blight pathogen. Nat Commun 2013;4:1424.

13. Fernandez J, Wilson RA. Cells in cells: morphogenetic and metabolic strategies conditioning rice infection by the blast fungus Magnaporthe oryzae. Protoplasma. 2014;251:37-47.

14. Thornton CR, Wills OE. Immunodetection of fungal and oomycete pathogens: established and emerging threats to human health, animal welfare and global food security. Crit Rev Microbiol. 2013:1-25: doi:10.3190/ 1040841 X.2103.78895.

15. Dagenais TRT, Keller NP. Pathogenesis of Aspergillus fumigatus in Invasive Aspergillosis. Clin Microbiol Rev. 2009;22(3):447-65.

16. Quail MA, Smith M, Coupland P, Otto TD, Harris SR, Connor TR, et al. A tale of three next generation sequencing platforms: comparison of lon Torrent, Pacific Biosciences and Illumina MiSeq sequencers. BMC Genomics. 2012;13:341.

17. Zhang J, Chiodini R, Badr A, Zhang G. The impact of next-generation sequencing on genomics. J Genet Genomics. 2011:38(3):95-109.

18. Bustin SA, Benes V, Nolan T, Pfaffl MW. Quantitative real-time RT-PCR-a perspective. J Mol Endocrinol. 2005;34:597-601.

19. Wong ML, Medrano JF. Real-time PCR for mRNA quantitation. BioTechniques. 2005;39(1):75-85.

20. Derveaux S, Vandesompele J, Hellemans J. How to do successful gene expression analysis using real-time PCR. Methods. 2010;50(4):227-30.

21. Huggett J, Bustin SA. Standardisation and reporting for nucleic acid quantification. Accreditation Qual Assur. 2011;16:399-405.

22. Bustin SA, Benes V, Garson JA, Hellemans J, Huggett J, Kubista M, et al. The MIQE guidelines: minimum information for publication of quantitative real-time PCR experiments. Clin Chem. 2009;55(4):611-22.

23. Huggett J, Dheda K, Bustin S, Zumla A. Real-time RT-PCR normalisation; strategies and considerations. Genes Immun. 2005;6:279-84.

24. Liu ZL, Slininger PJ. Universal external RNA controls for microbial gene expression analysis using microarray and qRT-PCR. J Microbiol Methods. 2007;68(3):486-96.

25. Devonshire AS, Elaswarapu R, Foy CA. Evaluation of external RNA controls for the standardisation of gene expression biomarker measurements. BMC Genomics. 2010;11:662.

26. Baker SC, Bauer SR, Beyer RP, Brenton JD, Bromley B, Burrill J, et al. The external RNA controls consortium: a progress report. Nat Methods. 2005;2(10):731-4.

27. Ramsden SC, Daly S, Geilenkeuser W-J, Duncan G, Hermitte F, Marubini E, et al. EQUAL-quant: an international external quality assessment scheme for real-time PCR. Clin Chem. 2006:52:1584-91.

28. Vandesompele J, Kubista M, Pfaffl MW. Reference gene validation software for improved normalization. In: Logan J, Edwards K, Saunders N, editors. Real-time PCR: current technology and applications, vol. 47. Norfolk, UK: Caister Academic Press; 2009. p. 64

29. Thellin O, EIMoualij B, Heinen E, Zorzi W. A decade of improvements in quantification of gene expression and internal standard selection. Biotechnol Adv. 2009;27(4):323-33.

30. Hruz T, Wyss M, Docquier M, Pfaffl MW, Masanetz S, Borghi L, et al. RefGenes: identification of reliable and condition specific reference genes for RT-qPCR data normalization. BMC Genomics. 2011;12:156.

31. Kozera B, Rapacz M. Reference genes in real-time PCR. J Appl Genet. 2013;54:391-406

32. Andersen $\mathrm{CL}$, Jensen $\mathrm{J}$, Ørntoft TF. Normalization of real-time quantitative reverse transcription-PCR data: a model-based variance estimation approach to identify genes suited for normalization, applied to bladder and colon cancer data sets. Cancer Res. 2004;64:5245-50.

33. Vandesompele J, De Preter K, Pattyn F, Poppe B, Van Roy N, De Paepe A et al. Accurate normalization of real-time quantitative RT-PCR data by geometric averaging of multiple internal control genes. Genome Biol. 2002, 3:RESEARCH0034.

34. Pfaffl MW, Tichopad A, Prgomet C, Neuvians TP. Determination of stable housekeeping genes, differentially regulated target genes and sample integrity: BestKeeper - Excel-based tool using pair-wise correlations. Biotechnol Lett. 2004;26:509-15.

35. Bohle K, Jungebloud A, Göcke Y, Dalpiaz A, Cordes C, Horn H, et al. Selection of reference genes for normalisation of specific gene quantification data of Aspergillus niger. J Biotechnol. 2007;132(4):353-8.

36. Steiger MG, Mach RL, Mach-Aigner AR. An accurate normalization strategy for RT-qPCR in Hypocrea jecorina (Trichoderma reesei). J Biotechnol. 2010;145:30-7

37. Yan H-Z, Liou R-F. Selection of internal control genes for real-time quantitative RT-PCR assays in the oomycete plant pathogen Phytophthora parasitica. Fungal Genet Biol. 2006:43:430-8

38. Vieira A, Talhinhas P, Loureiro A, Duplessis S, Fernandez D, Silva M, et al. Validation of RT-qPCR reference genes for in planta expression studies in Hemileia vastatrix, the causal agent of coffee leaf rust. Fungal Biol. 2011;115:891-901. 
39. Zhou Y-H, Zhang Y-J, Luo Z-B, Fan Y-H, Tang G-R, Liu L-J, et al. Selection of optimal reference genes for expression analysis in the entomopathogenic fungus Beauveria bassiana during development, under changing nutrient conditions, and after exposure to abiotic stresses. Appl Microbiol Biotechnol. 2012;93:679-85.

40. Hacquard S, Veneault-Fourrey C, Delaruelle C, Frey P, Martin F, Duplessis S. Validation of Melampsora larici-populina reference genes for in planta RT-quantitative PCR expression profiling during time-course infection of poplar leaves. Physiol Mol Plant Pathol. 2011;75:106-12.

41. Raffaello T, Asiegbu FO. Evaluation of potential reference genes for use in gene expression studies in the conifer pathogen (Heterobasidion annosum). Mol Biol Rep. 2013;40(7):4605-11.

42. Fang W, Bidochka MJ. Expression of genes involved in germination, conidiogenesis and pathogenesis in Metarhizium anisopliae using quantitative real-time RT-PCR. Mycol Res. 2006;110(Pt 10):1165-71.

43. Zampieri D, Nora LC, Basso V, Camassola M, Dillon AJP. Validation of reference genes in Penicillium echinulatum to enable gene expression study using real-time quantitative RT-PCR. Curr Genet. 2014;60(3):231-6.

44. Zhang Y, Zhao J, Fang W, Zhang J, Luo Z, Zhang M, et al. Mitogen-activated protein kinase hog1 in the entomopathogenic fungus Beauveria bassiana regulates environmental stress responses and virulence to insects. Appl Environ Microbiol. 2009;75:3787-95.

45. Huang Xueling NA FU, Feng Hao NA FU, Kang Zhensheng FU, Kang Zhensheng NA. Selection of reference genes for quantitative real-time PCR normalization in Puccinia Striiformis f.sp. tritici. J Agric Biotechnol. 2012;20(2):181-7.

46. Kim HK, Yun SH. Evaluation of potential reference genes for quantitative RT-PCR analysis in Fusarium graminearum under different culture conditions. Plant Pathol J. 2011;27:301-9.

47. Laurell H, lacovoni JS, Abot A, Svec D, Maoret J-J, Arnal J-F, et al. Correction of RT-qPCR data for genomic DNA-derived signals with ValidPrime. Nucleic Acids Res. 2012;40:e51.

48. Barrett T, Wilhite SE, Ledoux P, Evangelista C, Kim IF, Tomashevsky M, et al. NCBI GEO: archive for functional genomics data sets-update. Nucleic Acids Res. 2013:41(Database issue):D991-5.

49. Edgar R, Domrachev M, Lash AE. Gene Expression Omnibus: NCBI gene expression and hybridization array data repository. Nucleic Acids Res. 2002;30:207-10.

50. Ries L, Pullan ST, Delmas S, Malla S, Blythe MJ, Archer DB. Genome-wide transcriptional response of Trichoderma reesei to lignocellulose using RNA sequencing and comparison with Aspergillus niger. BMC Genomics. 2013:14:541.

51. Delmas S, Pullan ST, Gaddipati S, Kokolski M, Malla S, Blythe MJ, et al. Uncovering the genome-wide transcriptional responses of the filamentous fungus Aspergillus niger to Lignocellulose using RNA sequencing. PLoS Genet. 2012;8:e1002875.

52. Lin J-Q, Zhao X-X, Zhi Q-Q, Zhao M, He Z-M. Transcriptomic profiling of Aspergillus flavus in response to 5-azacytidine. Fungal Genet Biol. 2013:56:78-86.

53. Yu J, Fedorova ND, Montalbano BG, Bhatnagar D, Cleveland TE, Bennett JW, et al. Tight control of mycotoxin biosynthesis gene expression in Aspergillus flavus by temperature as revealed by RNA-Seq. FEMS Microbiol Lett. 2011;322(2):145-9.

54. Wang B, Guo G, Wang C, Lin Y, Wang $X$, Zhao M, et al. Survey of the transcriptome of Aspergillus oryzae via massively parallel mRNA sequencing. Nucleic Acids Res. 2010;38(15):5075-87.

55. Coradetti ST, Xiong Y, Glass NL. Analysis of a conserved cellulase transcriptional regulator reveals inducer-independent production of cellulolytic enzymes in Neurospora crassa. MicrobiologyOpen. 2013;2(4):595-609.

56. O'Connell RJ, Thon MR, Hacquard S, Amyotte SG, Kleemann J, Torres MF, et al. Lifestyle transitions in plant pathogenic Colletotrichum fungi deciphered by genome and transcriptome analyses. Nat Genet. 2012:44:1060-5.

57. Tang JD, Parker LA, Perkins AD, Sonstegard TS, Schroeder SG, Nicholas DD, et al. Gene expression analysis of copper tolerance and wood decay in the brown rot fungus Fibroporia radiculosa. Appl Environ Microbiol. 2013;79:1523-33.

58. Soanes DM, Chakrabarti A, Paszkiewicz KH, Dawe AL, Talbot NJ. Genome-wide transcriptional profiling of appressorium development by the rice blast fungus Magnaporthe oryzae. PLoS Pathog. 2012;8:e1002514.
59. Coradetti ST, Craig JP, Xiong Y, Shock T, Tian C, Glass NL. Conserved and essential transcription factors for cellulase gene expression in ascomycete fungi. Proc Natl Acad Sci U S A. 2012;109:7397-402.

60. Znameroski EA, Coradetti ST, Roche CM, Tsai JC, lavarone AT, Cate JHD, et al. Induction of lignocellulose-degrading enzymes in Neurospora crassa by cellodextrins. Proc Natl Acad Sci U S A. 2012;109(16):6012-7.

61. Traeger S, Altegoer F, Freitag M, Gabaldon T, Kempken F, Kumar A, et al. The genome and development-dependent transcriptomes of Pyronema confluens: a window into fungal evolution. PLoS Genet. 2013;9:e1003820.

62. Teichert I, Wolff G, Kück U, Nowrousian M. Combining laser microdissection and RNA-seq to chart the transcriptional landscape of fungal development BMC Genomics. 2012;13:511.

63. Fernandez J, Wright JD, Hartline D, Quispe CF, Madayiputhiya N, Wilson RA Principles of carbon catabolite repression in the rice blast fungus: Tps1, Nmr1-3, and a MATE-family pump regulate glucose metabolism during infection. PLoS Genet. 2012;8:e1002673.

64. Georgakopoulos P, Lockington RA, Kelly JM. SAGA complex components and acetate repression in aspergillus nidulans. G3 GenesGenomesGenetics. 2012;2:1357-67.

65. Lozano-Ojalvo D, Rodríguez A, Bernáldez V, Córdoba JJ, Rodríguez M. Influence of temperature and substrate conditions on the omt-1 gene expression of Aspergillus parasiticus in relation to its aflatoxin production. Int J Food Microbiol. 2013;166:263-9.

66. McKelvey SM, Murphy RA. Analysis of wide-domain transcriptional regulation in solid-state cultures of Aspergillus oryzae. J Ind Microbiol Biotechnol. 2010;37:455-69.

67. Raggam RB, Salzer HJF, Marth E, Heiling B, Paulitsch AH, Buzina W. Molecular detection and characterisation of fungal heat shock protein 60 . Mycoses. 2011;54:e394-9.

68. Novodvorska M, Hayer K, Pullan ST, Wilson R, Blythe MJ, Stam H, et al. Transcriptional landscape of Aspergillus niger at breaking of conidial dormancy revealed by RNA-sequencing. BMC Genomics. 2013;14:246.

69. Lamarre C, Sokol S, Debeaupuis J-P, Henry C, Lacroix C, Glaser P, et al. Transcriptomic analysis of the exit from dormancy of Aspergillus fumigatus conidia. BMC Genomics. 2008;9:417.

70. Van Leeuwen MR, Krijgsheld P, Bleichrodt R, Menke H, Stam H, Stark J, et al. Germination of conidia of Aspergillus niger is accompanied by major changes in RNA profiles. Stud Mycol. 2013;74:59-70.

71. Guais O, Tourrasse O, Dourdoigne M, Parrou JL, Francois JM. Characterization of the family GH54 alpha-L-arabinofuranosidases in Penicillium funiculosum, including a novel protein bearing a cellulose-binding domain. Appl Microbiol Biotechnol. 2010;87:1007-21.

72. Silver N, Best S, Jiang J, Thein SL. Selection of housekeeping genes for gene expression studies in human reticulocytes using real-time PCR. BMC Mol Biol. 2006;7:33.

73. Die JV, Román B. RNA quality assessment: a view from plant qPCR studies. J Exp Bot. 2012;63:6069-77.

74. Vermeulen J, De Preter K, Lefever S, Nuytens J, De Vloed F, Derveaux S, et al. Measurable impact of RNA quality on gene expression results from quantitative PCR. Nucleic Acids Res. 2011;39:e63.

75. Lafond M, Guais O, Maestracci M, Bonnin E, Giardina T. Four GH11 xylanases from the xylanolytic fungus Talaromyces versatilis act differently on (arabino) xylans. Appl Microbiol Biotechnol. 2014;98(14):6339-52.

76. Teste M-A, Duquenne M, François JM, Parrou J-L. Validation of reference genes for quantitative expression analysis by real-time RT-PCR in Saccharomyces cerevisiae. BMC Mol Biol. 2009;10:99.

77. Faccioli P, Ciceri GP, Provero P, Stanca AM, Morcia C, Terzi V. A combined strategy of "in silico" transcriptome analysis and web search engine optimization allows an agile identification of reference genes suitable for normalization in gene expression studies. Plant Mol Biol. 2007;63(5):679-88.

78. Dheda K, Huggett JF, Chang JS, Kim LU, Bustin SA, Johnson MA, et al. The implications of using an inappropriate reference gene for real-time reverse transcription PCR data normalization. Anal Biochem. 2005;344:141-3. 